Georgetown University Law Center

Scholarship @ GEORGETOWN LAW

2010

\title{
"To Remand, or Not to Remand": Ventura's Ordinary Remand Rule and the Evolving Jurisprudence of Futility
}

Patrick J. Glen

Georgetown University Law Center, pjg32@law.georgetown.edu

Georgetown Public Law and Legal Theory Research Paper No. 10-32

This paper can be downloaded free of charge from:

https://scholarship.law.georgetown.edu/facpub/493

http://ssrn.com/abstract $=1576128$

10 Rich. J. Global L. \& Bus. (2010)

This open-access article is brought to you by the Georgetown Law Library. Posted with permission of the author. Follow this and additional works at: https://scholarship.law.georgetown.edu/facpub

Part of the Administrative Law Commons, Constitutional Law Commons, Immigration Law Commons, and the Jurisprudence Commons 


\title{
"TO REMAND, OR NOT TO REMAND": VENTURA'S ORDINARY REMAND RULE AND THE EVOLVING JURISPRUDENCE OF FUTILITY
}

\author{
Patrick J. Glen*
}

\section{INTRODUCTION}

Presumably few federal appellate judges are confronted with the Danish prince's existential angst: "To be, or not to be: that is the question. ..."1 Nonetheless, a similar ambivalence may be present in the circumstance of judicial review of administrative agency decisions. No less eminent an authority than former Second Circuit Judge Henry Friendly expressed just such angst in the introduction to his 1969 Duke Law Journal article, in which he attempted to discern bright-line rules in the Supreme Court's 1943 SEC v. Chenery ${ }^{2}$ decision: "Although when I began my labors, I had the hope of discovering a bright shaft of light that would furnish a sure guide to decision in every case, the grail has eluded me; indeed I have come to doubt that it exists. ${ }^{3}$ Determination when to reverse and remand a decision that an administrative agency had power to make, and sufficient evidence to support, is, I fear, perhaps more art than science." ${ }^{4}$ The nature and scope of judicial review of administrative decisions has taken on increasing importance as the size of the administrative state has grown and the number of administrative adjudicators has multiplied. As one commentator has noted, "[j]udicial review of administrative agency decisions is one of the cornerstones of the modern administrative law system[,] . . . although the nature and scope of judicial review, and the authority of the courts to dispose of these matters reflect a variety of approaches. ..."5 To a large degree, the question of whether and in what circumstances remand to the agency rather than a judicial decision in the first instance is required is still resolved with at least su-

\footnotetext{
* Adjunct Professor of Law, Georgetown University Law Center; Attorney, Office of Immigration Litigation, Civil Division, United States Department of justice. The views and opinions contained herein do not necessarily represent those of the Department of Justice or the United States government.

1 See William Shakespeare, Hamlet act 3, sc. 1.

2 SEC v. Cenery, 318 U.S. 80 (1943).

3 Henry J. Friendly, Chenery Revisited: Reflections on Reversal and Remand of Administrative Orders, 1969 Duke L.J. 199, 199-200 (1969).

${ }^{4} I d$.

5 Howard N. Fenton, Return to Sender: The Remand Puzzle in Ohio Administrative Law, 29 Oнiо N.U. L. REv. 395, 395 (2003).
} 
perficial reference to the Supreme Court's Chenery decision. In that decision, the Court laid out the basic precepts of judicial review of administrative action. "If the action rests upon an administrative determination-an exercise of judgment in an area which Congress has entrusted to the agency - of course it must not be set aside because the reviewing court might have made a different determination were it empowered to do so." 6 However, "if the action is based upon a determination of law as to which the reviewing authority of the courts does come into play, an order may not stand if the agency has misconceived the law."7 Thus, the Court gave voice to what would become the courts' deferential stance to agency factual findings and discretionary determinations, and its continuing authority to review legal and constitutional claims de novo.

In the years since Chenery, the Supreme Court has increasingly canonized the deference owed to administrative agencies in the discharge of their mandates, even as regards the resolution of legal issues. An administrative agency's interpretation of ambiguous provisions in the statute or statutes it is charged with administering is entitled to definitive deference on review so long as it is a reasonable and permissible construction of the statute. ${ }^{8}$ Moreover, if the statutory "gap," i.e., ambiguity, is the result of an express delegation to the agency by Congress of the authority to render a definitive interpretation, that interpretation is conclusive unless "arbitrary, capricious, or manifestly contrary to the statute." 9 The Supreme Court has also recently made clear that deference to the agency under Chevron must be granted even if the agency's interpretation is contrary to prior judicial resolutions of the issue: "A court's prior judicial construction of a statute trumps an agency construction otherwise entitled to Chevron deference only if the prior court decision holds that its construction follows from the unambiguous terms of the statute and leaves no room for agency discretion."10 Likewise, the agency's construction and interpretation of its regulations is also entitled to substantial deference on review so long as that interpretation is reasonable. ${ }^{11}$ Accordingly, the determinations of administrative agencies as a general matter en-

\footnotetext{
${ }^{6}$ Chenery, 318 U.S. at 94.

${ }^{7} \mathrm{Id}$.

8 See Chevron U.S.A., Inc. v. Natural Res. Def. Council, 467 U.S. 837, 843-44 (1984).

${ }^{9} \mathrm{Id}$.

10 Nat'l Cable \& Telecomm. Ass'n v. Brand X Internet Servs., 545 U.S. 967, 982 (2005).

11 See Auer v. Robbins, 519 U.S. 452, 459 (1997); INS v. Nat'l Ctr. for Immigrants' Rights, Inc., 502 U.S. 183, 194 (1991); Bowles v. Seminole Rock \& Sand Co., 325 U.S. 410, 414 (1945).
} 
joy substantial deference on review, both as to factual and legal matters.

The deference owed administrative decisions in general is, if anything, heightened in the context of immigration law on account of the nature and implications of the decisions being made. As the Supreme Court has noted, "judicial deference to the Executive Branch is especially appropriate in the immigration context where officials 'exercise especially sensitive political functions that implicate questions of foreign relations." "12 Decisions by the Attorney General and his delegates in the field of immigration "may affect our relations with . . . [another] country or its neighbors. The judiciary is not well positioned to shoulder primary responsibility for assessing the likelihood and importance of such diplomatic repercussions." 13

The issue presented by this article does not address deference to agency action as a general matter, but rather confronts a specific corollary of that principle: decisions entrusted to the agency must be made by the agency in the first instance prior to resolution by the courts of appeals. Accordingly, if a decision must turn on a determination that the agency for some reason has not yet made, the courts of appeals should generally remand the matter for determination by the agency in the first instance rather than resolving that issue de novo during the appellate process. Additionally, if there are errors in the agency decision at issue, whether factual or legal, proceedings should be remanded by the appellate court after identification of the errors, so that the agency may reconsider the claims anew without the prior flaws in its reasoning or rationale. This general rule pertaining to remand was enunciated in the administrative context in the Chenery decision, and given specific weight in the immigration context by the Supreme Court's 2002 decision in INS v. Ventura. ${ }^{14}$ Nonetheless, since the Supreme Court's Ventura decision a line of jurisprudence has evolved in the immigration context concerning whether remand would

12 INS v. Aguirre-Aguirre, 526 U.S. 415, 425 (1999) (quoting INS v. Abudu, 485 U.S. 94, 110 (1988)); see also Miller v. Albright, 523 U.S. 420, 434 n.11 (1998) ("Deference to the political branches dictates 'a narrow standard of review of decisions made by the Congress or the President in the area of immigration and naturalization."' (quoting Mathews v. Diaz, 426 U.S. 67, 82 (1976)); Abudu, 485 U.S. at 110 ("although all adjudications by administrative agencies are to some degree judicial and to some degree political and therefore an abuse-of-discretion standard will often apply to agency adjudications not governed by specific statutory commands-INS officials must exercise especially sensitive political functions that implicate questions of foreign relations, and therefore the reasons for giving deference to agency decisions on petitions for reopening or reconsideration in other administrative contexts apply with even greater force in the INS context.").

13 Aguirre-Aguirre, 526 U.S. at 425.

14 INS v. Ventura, 537 U.S. 12 (2002) (per curiam). 
be futile and thus the court should dispose of the relevant issue in the first instance, despite the fact that the agency has not rendered a decision as an initial matter, or has not been provided with the opportunity to render a decision free of any errors identified by the court on review. The purpose of the instant article is to assess the legitimacy of this evolving jurisprudence in light of general administrative law principles governing remand to agency adjudicators and the Supreme Court's iteration of the "ordinary remand rule" in the Ventura line of cases. ${ }^{15}$

Section I of this article will address the issue of remands from an administrative law perspective, tracing the development of the rules for judicial review from the Supreme Court's Chenery decision, through that Court's subsequent clarifications of the "rule" of Chenery, up to current circuit court practice concerning when remand is necessary and when the court can resolve the issue without the delay of remand. This section will also explore circuit court practice pre-Ventura regarding when petitions for review of Board of Immigration Appeals' decisions should be remanded and when the court could grant or deny the petition notwithstanding flaws in the underlying agency decision. Section II will address the Supreme Court's line of cases enunciating and clarifying the "ordinary remand rule," from Ventura, through Gonzales v. Thomas, ${ }^{16}$ and culminating in the recent decision in Negusie v. Holder. ${ }^{17}$ The evolving circuit court jurisprudence of the futility of remand is the focus of Section III, with special emphasis on the case law of the Second Circuit, which has the most developed line of precedent on this issue. Nonetheless, in addition to the Second Circuit, cases from the First, Fourth, Fifth, Sixth, Seventh, Ninth, and Eleventh Circuits will also be analyzed, as each has at least one case confronting the question of whether remand for further proceedings would be futile. Finally, Section IV seeks to answer the potentially complicated question of whether this jurisprudence of futility is in tension with, or complementary to, the Supreme Court's "ordinary remand rule." Although this enterprise may itself be futile, in light of Judge Friendly's assertion that the decision to remand is more akin to art than science, at the very least this article aims to discern the broad "scientific" rules within which the ultimate, artful decision to remand may take place.

\section{REMAND IN ADMINISTRATIVE LAW}

The instant section proceeds in two subsections. The first will address the administrative law principles governing remands as a gen-

\footnotetext{
15 Id. at 17.

16 Gonzales v. Thomas, 547 U.S. 183 (2006) (per curiam).

17 Negusie v. Holder, 129 S. Ct. 1159 (2009).
} 
eral matter, i.e., what rules courts of appeals should follow on review regarding when to dispose of issues in the first instance, and when to return matters to the administrative agency for further proceedings. The second subsection addresses the specific practice of the courts of appeals in immigration law, pre-Ventura, regarding when to grant or deny a petition for review regardless of errors in the agency decision, and when the matter should be remanded to the Board for further consideration in light of the noted errors.

\section{A. Elucidating the Rule of Chenery}

The typical avenue for obtaining judicial review of an agency action or decision is by filing a petition for review in the appropriate federal court of appeals. ${ }^{18}$ The court will then either grant or deny the petition. "In most cases, successful prosecution of a [petition for] review . . . yields . . . a judicial decision setting aside the agency action and remanding the proceeding for further agency action not inconsistent with the decision of the reviewing court." ${ }^{19}$ This presumption of remand is based on the agency's primacy in investigating matters within its competency and rendering a decision on those issues in the first instance, and in the fact that the courts of appeals are "not generally empowered to conduct a de novo inquiry into the matter being reviewed and to reach its own conclusions based on such an inquiry." It is, however, simply a presumption, and the Supreme Court has recognized that there will be "rare circumstances" where a remand to the agency for further proceedings is not necessary. ${ }^{21}$

What constitutes "rare circumstances" excusing the court from remanding a matter to the agency? Such circumstances may arise "if the legal issue presented admits of only one possible outcome or if the agency has committed an error of law." 22 In a slightly different construction, "[a] reviewing court can order an agency to provide the relief it denied only in the unusual case where the court concludes that the underlying law and facts are such that the agency has no discretion to

18 See, e.g., Immigration and Nationality Act ("INA") § 242; 8 U.S.C. § 1252 (2006) (detailing the requirements for obtaining judicial review of a final order of removal).

193 Richard J. Pierce, Jr., Administrative Law Treatise $§ 18.1$ (5th ed. 2010).

20 Fla. Power \& Light Co. v. Lorion, 470 U.S. 729, 744 (1985).

21 See, e.g., Lorion, 470 U.S. at 744 ("If the record before the agency does not support the agency action, if the agency has not considered all relevant factors, or if the reviewing court simply cannot evaluate the challenged agency action on the basis of the record before it, the proper course, except in rare circumstances, is to remand to the agency for additional investigation or explanation.") (emphasis added).

${ }^{22}$ Toni M. Fine, Agency Requests for "Voluntary" Remand: A Proposal for the Development of Judicial Standards, 28 ARIz. ST. L.J. 1079, 1105 (1996). 
act in any other manner, and then only when the court concludes that a remand to the agency would produce substantial injustice in the form of further delay of the action to which the petitioner is clearly entitled." ${ }^{23}$ Or, finally, in the simple words of the United States Court of Appeals for the District of Columbia Circuit, "[o]n occasion . . . we find a remand would be futile on certain matters as only one disposition is possible as a matter of law. In such cases, we retain and decide the issue." 24 It is worth noting, however, that even in those "rare circumstances" when remand may be dispensed with, there is no rule that compels dispensing with remand and deciding the issue in the first instance. Rather, "[i]n such cases, the court may correct the agency's legal error and remand for agency compliance or may dispense altogether with a remand and order a final disposition." 25 The question of whether to actually remand or not is largely dependent on prudential or pragmatic considerations once the court concludes the situation presented falls within the scope of the "rare circumstances" exception.

The dividing line between situations where a remand is required and those in which a remand may be foregone is somewhat mythic in actuality, as there are no clear tests to be applied across the range of administrative cases in which judicial review may be sought. The existence of such a line, however, is traceable to the Supreme Court's Chenery decision, notwithstanding the fact that the Supreme Court and federal appellate courts have been "modifying" the placement of that line over the better part of the past six decades. In Chenery, the Supreme Court was called upon to review an order of the Securities and Exchange Commission which was based in large part on the Commission's reading of the law of equity. ${ }^{26}$ The Supreme Court determined that the order could not be sustained, as the Commission's basis for that order was not firmly grounded in existing principles of equity, but rather on interpretations that would represent an advancement in that area of law as then understood. ${ }^{27}$ In vacating the order and remanding proceedings to the Commission, the Supreme Court declined to offer any views as to what order the Commission

\footnotetext{
233 Richard J. Pierce, Jr., Administrative Law Treatise $§ 18.1$ (5th ed. 2010) (citing Faucher v. Sec'y of Health \& Human Servs., 17 F.3d 171, 176 (6th Cir. 1994); Cissell Mfg.Co. v. Dep't of Labor, 101 F.3d 1132 (6th Cir. 1996); Ward v. Brown, 22 F.3d 516, 522-23 (2d Cir. 1994)).

${ }^{24}$ George Hyman Const. Co. v. Brooks, 963 F.2d 1532, 1539 (D.C. Cir. 1992); see also Wilkett v. ICC, 710 F.2d 861, 865 (D.C. Cir. 1983) ("As the finding of unfitness is clearly in error, the Commission is directed to issue the authority requested.").

25 Fine, supra note 22, at 1105.

26 SEC v. Cenery, 318 U.S. 80, 89 (1943).

${ }^{27}$ Id. at 94.
} 
could adopt upon remand, once it freed itself of the errors the Court had identified:

In finding that the Commission's order cannot be sustained, we are not imposing any trammels on its powers. We are not enforcing formal requirements. We are not suggesting that the Commission must justify its exercise of administrative discretion in any particular manner or with artistic refinement. We are not sticking in the bark of words. We merely hold that an administrative order cannot be upheld unless the grounds upon which the agency acted in exercising its powers were those upon which its action can be sustained. ${ }^{28}$

The Court thus gave voice to the first great iteration of administrative primacy within the scope of its mandate:

If an order is valid only as a determination of policy or judgment which the agency alone is authorized to make and which it has not made, a judicial judgment cannot be made to do service for an administrative judgment. For purposes of affirming no less than reversing its orders, an appellate court cannot intrude upon the domain which Congress has exclusively entrusted to an administrative agency. ${ }^{29}$

On remand, the Commission's substantive order remained the same, but its reasoning was, on appeal, upheld as permissible, freed as it was from the prior reliance on its interpretation of equitable principles. ${ }^{30}$ Although the prior reasoning of the Commission was not sufficient to sustain its order, its subsequent rationale was and, as the sole flaw in the initial order was its reliance on impermissible bases, the "new" order was sustainable even though it was substantively identical to the prior, vacated order. In its second Chenery decision, the Court distilled the main import of its prior decision:

When the case was first here, we emphasized a simple but fundamental rule of administrative law. That rule is to the effect that a reviewing court, in dealing with a determination or judgment which an administrative agency alone is authorized to make, must judge the propriety of such action solely by the grounds invoked by the agency. If those grounds are inadequate or improper, the court is powerless to affirm the administrative action by substituting what it considers to be a more adequate or

\footnotetext{
28 Id. at 95 .

29 Id. at 88.

30 SEC v. Chenery, 332 U.S. 194 (1947).
} 
proper basis. To do so would propel the court into the domain which Congress has set aside exclusively for the administrative agency. ${ }^{31}$

The "remand rule" of the Chenery cases seems absolute in scope. If the agency has not yet rendered a decision on the relevant issue, or has committed an error in reaching its disposition, a reviewing court cannot affirm or deny the appeal and must remand for an agency decision in the first instance, or an agency decision freed of the underlying error. ${ }^{32}$ Even if the rule could have been stated in such absolutist terms at some point in the distant past, subsequent practice by the Supreme Court and the federal courts of appeals have eroded its universalist pretensions.

In a 1964 case, it was contended that the Maritime Commission had failed to adequately note or ground its statutory authority for enacting its profit-sharing arrangement of vessel rentals pursuant to the Merchant Ship Sales Act. ${ }^{33}$ The Supreme Court held that the question of what statutory provision the Commission assumed its relevant authority was vested in was irrelevant to its ultimate decision to enact the agreement and thus, even assuming there was error in the Commission's stated basis of authority in entering into the disputed contract, that error would not have altered the agreed upon resolution. ${ }^{34}$ To so hold, however, the Court had to explicitly confront the contention that Chenery dictated a remand so that the Commission could clarify its motivation in enacting the agreement. The Court disagreed that remand was warranted or necessary in light of its conclusion that even assuming error, that error did not impact the substance of the decision reached:

[W]e find inapposite here cases refusing to validate an exercise of administrative discretion because it could have been supported by principles or facts not considered, or procedures not undertaken, by the responsible body. These cases are aimed at assuring that initial administrative determinations are made with relevant criteria in mind and in a proper procedural manner; when a mistake of the administrative body is one that clearly had no bearing on the procedure used or the substance of the decision reached, as in this instance...., the sought

\footnotetext{
31 Id. at 196.

${ }^{32} \mathrm{Id}$.

33 Mass. Tr. of E. Gas \& Fuel Assocs. v. United States, 377 U.S. 235, 241 (1964).

${ }^{34}$ Id. at 246-47.
} 
\begin{tabular}{llrrr}
\hline$\backslash$ server05\productn $\backslash R \backslash R G L \backslash 10-1 \backslash$ RGL101.txt & unknown & Seq: 9 & 2-DEC-10 & $14: 58$ \\
\hline
\end{tabular}

extension of the cases cited [including Chenery] would not advance the purpose they were intended to serve. ${ }^{35}$

Five years later, and over the dissent of four justices on the remand issue, the Supreme Court declined to remand a case to the National Labor Relations Board for further proceedings, concluding that such a remand would be futile in light of the Court's conclusion that the Board would undoubtedly reach the same disposition even assuming error in its underlying decision then on review. ${ }^{36}$ The Court again took aim at Chenery and the argument that remand was required once any error was discerned in the administrative action at issue:

To remand would be an idle and useless formality. Chenery does not require that we convert judicial review of agency action into a ping-pong game. In Chenery, the Commission had applied the wrong standards to the adjudication of a complex factual situation, and the Court held that it would not undertake to decide whether the Commission's result might have been justified on some other basis. Here, by contrast, the substance of the Board's command is not seriously contestable. There is not the slightest uncertainty as to the outcome of a proceeding before the Board, whether the Board acted through a rule or an order. It would be meaningless to remand. ${ }^{37}$

Despite these subsequent clarifications of Chenery, its fundamental premise remains sound, as the Supreme Court made clear just three terms ago in National Association of Home Builders v. Defenders of Wildlife. ${ }^{38}$ In a decision by the Ninth Circuit, the court concluded that an action taken by the Environmental Protection Agency was arbitrary and capricious, recognized that remand was the generally required course of action in such circumstances, but then went on to review the statutory scheme at issue and render a definitive interpretation of that statute in the first instance. ${ }^{39}$ Rehearing en banc was denied over the dissent of six judges, who argued that if the EPA's analysis was indeed faulty, then the proper course of action was remand, not a judgment by the Ninth Circuit in the first instance re-

${ }^{35} I d$. at 247-48. For an explication of this decision, see Friendly, supra note 3, at $210-11$.

36 NLRB v. Wyman-Gordon, Co., 394 U.S. 759 (1969); see generally The Supreme Court, 1968 Term, Prospective Rulings in Agency Adjudication, 83 Harv. L. Rev. 220 (1969).

37 Wyman-Gordon, Co., 394 U.S. at 766 n.6.

38 Nat'l Ass'n of Home Builders v. Defenders of Wildlife, 551 U.S. 644, 684 (2007).

39 Defenders of Wildlife v. EPA, 420 F.3d 946 (9th Cir. 2005). 
garding a statute that the EPA was charged with administering. ${ }^{40}$ The Supreme Court reversed the Ninth Circuit on the merits, determining that the EPA's construction of the statute was reasonable and permissible, and chastised the court for overstepping its authority in its review of the agency's order:

[T] he court below expressly recognized that [its] finding required it to "remand to the agency for a plausible explanation of its decision, based on a singly, coherent interpretation of the statute." But the Ninth Circuit did not take this course; instead, it jumped ahead to resolve the merits of the dispute. In so doing, it erroneously deprived the agency of its usual administrative avenue for explaining and reconciling the arguably contradictory rationales that sometimes appear in the course of lengthy and complex administrative decisions. ${ }^{41}$

In the end, is there a coherent set of principles embodied by the Chenery line of cases? Judge Friendly extracted three basic rules in his exposition of the cases as they stood in 1969. ${ }^{42}$ First, "even when an agency has acted on an admissible construction of the statute and has made sufficient factual findings, a reviewing court may still reverse and remand if the agency has not adequately explained why it chose to do what it did." 43 Second, "[w] here the agency has rested decision on an unsustainable reason, the court should generally reverse and remand even though it discerns a possibility, even a strong one, that by another course of reasoning the agency might come to the same result." ${ }^{44}$ Third, reversal and remand is required where there are inadequate or erroneous findings. ${ }^{45}$ Nonetheless, regarding Friendly's last rule, "reversal and remand are [not] required each and every time an administrative agency assigns a wrong reason for its action; rather, it requires reversal and remand only where there is a significant chance that but for the error, the agency might have reached a differ-

${ }^{40}$ Defenders of Wildlife v. EPA, 450 F.3d 394, 396-97 (9th Cir. 2006).

41 Nat'l Ass'n of Home Builders, 551 U.S. at 657-58.

42 Friendly, supra note 3 , at 222.

43 Id.

${ }^{44}$ Id.; cf. Cajun Elec. Power Coop., Inc. v. FERC, 924 F.2d 1132 (D.C. Cir. 1991) (noting that remand is required to permit an agency to exercise its primacy in statutory interpretation when an agency discerns no ambiguity in statutory language, rests it relevant decision on that basis, but the court concludes that there is an ambiguity in need of resolution) (citing Baltimore \& Ohio R.R. v. ICC, 826 F.2d 1125, 1128-29 (D.C. Cir. 1987)).

45 Friendly, supra note 3, at 223. 
ent result." ${ }^{46}$ Thus, the presumption of remand stands unchanged in 2010 , but it is as clear as ever that this is a rebuttable presumption which may be overcome in the right circumstances.

\section{B. Remands in Immigration Law Pre-Ventura}

This subsection addresses the practice of the federal courts of appeals, pre-Ventura, in exercising their discretion to hold and decide a case, consistent with the Chenery line of decisions, notwithstanding the existence of errors in the underlying administrative order. These decisions can be largely grouped into three illustrative, though not exhaustive categories.

First, the courts generally declined to remand matters to the agency where errors were present in the agency's determination of an alien's statutory eligibility for discretionary relief, but where the agency also decided, or made clear it would decide, that such relief would not be granted in the exercise of its discretion regardless of technical eligibility. ${ }^{47}$ Thus, in Dhine v. Slattery, the Second Circuit declined to remand a petition to the Board for further proceedings despite potential errors in the agency's findings with respect to the alien's fear of persecution if removed, because the agency had also determined that asylum would be denied in the exercise of its discretion, thus rendering any errors in the eligibility determination irrelevant to the ultimate disposition. ${ }^{48}$ That court similarly denied remand in $\mathrm{Hib}$ bert $v$. INS on the ground that voluntary departure would be denied in the exercise of discretion, rendering futile any further proceedings to determine the alien's technical statutory eligibility for that form of discretionary relief. ${ }^{49}$ In a more recent case from the First Circuit, however, that court determined that a remand was necessary, as there was error in the agency's determination regarding the alien's eligibility for asylum, and there was no clear indication that such relief would be denied in the exercise of discretion if the alien was found to be statutorily eligible. ${ }^{50}$

The second category of cases concerns those situations akin to harmless error analysis; i.e., the court determines that no remand is

46 NLRB v. Am. Geri-Care, Inc., 697 F.2d 56, 64 (2d Cir. 1982) (citing NLRB v. Wyman-Gordon, Co., 394 U.S. 759, 766 n.6 (1969)); see also Pfizer, Inc. v. Richardson, 434 F.2d 536, 547 n.21 (2d Cir. 1970).

47 To a large extent, this rationale is embodied in the Supreme Court's decision in INS $v$. Bagamasbad, where the Court held that an agency need decide only those arguments that are necessary in order for it to dispose of the issues presented. 429 U.S. 24 (1976),

${ }^{48}$ Dhine v. Slattery, 3 F.3d 613, 619-20 (2d Cir. 1993).

49 Hibbert v. INS, 554 F.2d 17, 21 (2d Cir. 1977).

${ }^{50}$ Gebremichael v. INS, 10 F.3d 28, 36-37 (1st Cir. 1993). 
warranted because there has been no showing that, but for the purported error, the proceedings may have come out differently. The Ninth Circuit denied remand in Tejeda-Mata v. INS on this ground, holding that, although the immigration judge did abuse his discretion in not allowing simultaneous translation of the alien's removal proceedings, it was clear that this error did not have any deleterious effect on the outcome of the proceeding and thus the result would not change if the case was remanded and this error remedied. ${ }^{51}$ Similarly, the Seventh Circuit denied remand in Dobrota $v$. INS despite finding error in the agency's consideration of the alien's claim of past persecution in Romania, because the subsequent change in country conditions in Romania made clear that the alien would not possess an objectively reasonable well-founded fear of persecution if removed. ${ }^{52}$

Finally, remand has been denied in circumstances where the court determines that there is but one conclusion that the agency could reach on remand, even if the agency did not reach the issue found dispositive by the court. In Navas $v$. INS, the Ninth Circuit reversed the agency's determination that an applicant failed to establish past persecution, but did not remand for a determination of whether changed country conditions could rebut the presumption of future persecution, because the court found the record clearly indicated the well-founded fear of persecution could not be rebutted. ${ }^{53}$ The First Circuit granted a petition for review in Fergiste $v$. INS on this same basis. ${ }^{54}$ Judge Selya dissented in part from that disposition, arguing that remand was the appropriate remedy to ensure the burden of proof for establishing or rebutting a well-founded fear of persecution was correctly allocated, and to permit consideration of all relevant evidence regarding whether any presumption of persecution could be rebutted. ${ }^{55}$ The bulk of cases falling into this category are those in which the courts have found some error in the agency's determination regarding eligibility for asylum or other discretionary relief, held that the alien is in fact eligible when those errors are purged, and remanded solely to permit the Attorney General to exercise his discretion in granting or denying that relief. ${ }^{56}$

This review may indicate that the courts were all too willing to decide, in the first instance, issues delegated to the agency. That is

\footnotetext{
51 Tejada-Mata v. INS, 626 F.2d 721, 726-27 (9th Cir. 1980).

52 Dobrota v. INS, 195 F.3d 970, 973-74 (7th Cir. 1999).

${ }^{53}$ Navas v. INS, 217 F.3d 646, 657-58 (9th Cir. 2000).

54 Fergiste v. INS, 138 F.3d 14, 21 (1st Cir. 1998).

${ }^{55}$ Id. at 21-22 (Selya, J., concurring in part, dissenting in part) ("To be sure, in some cases the record may be so pellucid that remand would be an empty exercise. But, I see no indication that this is such a case.").

56 See Gafoor v. INS, 231 F.3d 645 (9th Cir. 2000); Aguilera-Cota v. INS, 914 F.2d 1375 (9th Cir. 1990); Bolanos-Hernandez v. INS, 767 F.2d 1277 (9th Cir. 1984).
} 
not entirely accurate. The courts' disposition of these immigration cases is consistent with their disposition of other administrative law issues. Remand is the presumption, but that presumption may be overcome. Nonetheless, at least in light of the subsequent Supreme Court decisions addressing the application of the "ordinary remand rule" in the immigration context, the courts presumed, or arrogated, authority was broader pre-Ventura than it is on any fair reading of Ventura and its progeny. Those cases are the subject of the next section.

\section{INS V. VENTURA, GONZALES V. THOMAS, AND NEGUSIE V. HOLDER: THE "ORDINARY REMAND RULE" IN IMMIGRATION LAW}

Orlando Ventura, a native and citizen of Guatemala, fled that country after allegedly receiving numerous threats from the guerrillas that he should either join them or face the consequences. ${ }^{57}$ Ventura purportedly had family members who were serving or had served in the Guatemalan military, and he alleged that the guerrillas perceived him to be their enemy on this account. ${ }^{58}$ After hearing his claims, an immigration judge determined that he failed to establish eligibility for asylum or withholding of removal, as he could not establish that any persecution alleged or feared was on account of one of the five enumerated statutory grounds of protection. ${ }^{59}$ Additionally, the immigration judge found no reasonable fear of persecution "[i]n view of changing country conditions" in Guatemala. ${ }^{60}$ Ventura appealed to the Board, but his appeal was dismissed. The Board based its decision solely on Ventura's failure to demonstrate that the persecution alleged or feared was on account of a statutorily protected ground, and did not reach the

57 Ventura v. INS, 264 F.3d 1150, 1152-53 (9th Cir. 2001).

${ }^{58}$ Id. at 1153.

${ }^{59}$ Id. See INA $\S 101(\mathrm{a})(42), \S 1101(\mathrm{a})(42)$ (2006) (an applicant for asylum and withholding of removal must establish persecution or a well-founded fear of persecution on account of race, religion, nationality, membership in a particular social group, or political opinion); INA § 208, 8 U.S.C. $\$ 1158$ (2006) (standard and burden of proof for establishing eligibility for asylum); INA $\S 241(b)(3), 8$ U.S.C. $\S 1231(\mathrm{~b})(3)$ (2006) (standard and burden of proof for establishing eligibility for withholding of removal).

${ }^{60}$ Ventura, 264 F.3d at 1153. An applicant for asylum or withholding of removal who establishes past persecution is entitled to a presumption of a well-founded and clear probability of persecution if removed. See 8 C.F.R. $\S \S 1208.13(b)(1)$, 1208.16(b)(1)(i) (2010). This presumption may be rebutted by establishing, inter alia, a change in country conditions in the applicant's native country such that there is no longer an objectively reasonable fear of persecution. See 8 C.F.R. $\S \S 1208.13(\mathrm{~b})(1)(\mathrm{i})(\mathrm{A}), 1208.16(\mathrm{~b})(1)(\mathrm{i})(\mathrm{A})(2010)$. 
issue of whether changed country conditions in Guatemala would undercut any claim of future persecution. ${ }^{61}$

Ventura filed a petition for review with the Ninth Circuit, which granted the petition. That court held that Ventura did establish that the persecution alleged was on account of a statutorily protected ground, specifically, an imputed political opinion. ${ }^{62}$ As the court held Ventura established past persecution, it determined that he was entitled to the regulatory presumption of a fear of persecution if he was removed. ${ }^{63}$ Although the Board did not reach the issue of whether the government could rebut this presumption, and thus there was no agency finding on that issue before the court, the Ninth Circuit nonetheless held that remand was not warranted: "We do not remand . . . when it is clear that we would be compelled to reverse the BIA's decision if the BIA decided the matter against the applicant." ${ }^{\prime 4}$ On the record before it, the court concluded that "remand in this case is inappropriate because the INS's evidence of changed country conditions clearly demonstrates that the presumption of a well-founded fear of persecution was not rebutted." 65 In support of this proposition, the court cited to the State Department Country Reports which indicated continuing levels of political tension and violence in Guatemala. ${ }^{66}$ Thus, the court determined Ventura was statutorily eligible for withholding of removal and asylum based on the unrebutted presumption of future persecution, granted his application for withholding of removal, as that form of protection is mandatory once statutory eligibility has been established, and remanded proceedings to the Board for the sole purpose of permitting the agency to exercise its discretion in granting or denying the application for asylum. ${ }^{67}$

The government filed a petition for a writ of certiorari and, without further briefing or argument, the Supreme Court granted the

61 Ventura, 264 F.3d at 1153.

62 See id. at 1154-57.

${ }^{63}$ Id. at 1157; see 8 C.F.R. $\S$ 1208.13(b)(1), 1208.16(b)(1)(i) (2010).

64 Ventura, 264 F.3d at 1157.

${ }^{65}$ Id. See 8 C.F.R. $\S \S 1208.13(\mathrm{~b})(1)(\mathrm{i})(\mathrm{A})$, 1208.16(b)(1)(i)(A) (2010).

${ }^{66}$ Ventura, 264 F.3d at 1157-58.

${ }^{67}$ Id. at 1158; see INA $\S 208(\mathrm{~b})(1)(\mathrm{A}), 8$ U.S.C. $\S 1158(\mathrm{~b})(1)(\mathrm{A})$ ("The . . . Attorney General may grant asylum to an alien who has applied for asylum.") (emphasis added); INA $\S 241(\mathrm{~b})(3)(\mathrm{A}), 8$ U.S.C. $\S 1231(\mathrm{~b})(3)(\mathrm{A})$ (“[T] not remove an alien to a country if the Attorney General decides that the alien's life of freedom would be threatened in that country.") (emphasis added); see also Aguirre-Aguirre, 526 U.S. at 420 ("[W]hereas withholding is mandatory unless the Attorney General determines one of the exceptions applies, the decision whether asylum should be granted to an eligible alien is committed to the Attorney General's discretion.") (citing INS v. Cardoza-Fonseca, 480 U.S. 421, 428-29, n.6 (1987)). 
petition and summarily reversed the Ninth Circuit on the ground that its determination of an issue, without prior resolution by the administrative agency in the first instance, was in excess of its legal authority as a reviewing court. ${ }^{68}$ The Supreme Court noted that the Immigration and Nationality Act entrusts to the agency the decision of whether or not an alien is eligible for asylum, and thus the agency has primacy in resolving that issue. ${ }^{69}$ If the agency has not reached the relevant issue in the course of the administrative proceedings, and the reviewing court determines that resolution of that issue is necessary to the ultimate disposition of the petitioner's case, then "the proper course, except in rare circumstances, is to remand to the agency for additional investigation or explanation."70 The Court further clarified the reach and rationale behind the ordinary remand rule, as well as its specific importance in the context of immigration law:

Generally speaking, a court of appeals should remand a case to an agency for decision of a matter that statutes place primarily in agency hands. This principle has obvious importance in the immigration context. The BIA has not yet considered the 'changed circumstances' issue. And every consideration that classically supports the law's ordinary remand requirement does so here. The agency can bring its expertise to bear upon the matter; it can evaluate the evidence; it can make an initial determination; and, in doing so, it can, through informed discussion and analysis, help a court later determine whether its decision exceeds the leeway that the law provides. ${ }^{71}$

Applying those considerations to the decision on review, the Court had little trouble in concluding that the "Court of Appeals committed clear error here. It seriously disregarded the agency's legally mandated role. . . . And it did so without giving the BIA the opportunity to address the matter in the first instance in light of its own experience."72 Accordingly, insofar as the Ninth Circuit had reached and decided the issue of changed country conditions, its decision was reversed and proceedings remanded so that the Ninth Circuit could in turn remand proceedings to the Board.

In the wake of Ventura, two other Ninth Circuit cases then pending before the Supreme Court were summarily reversed and re-

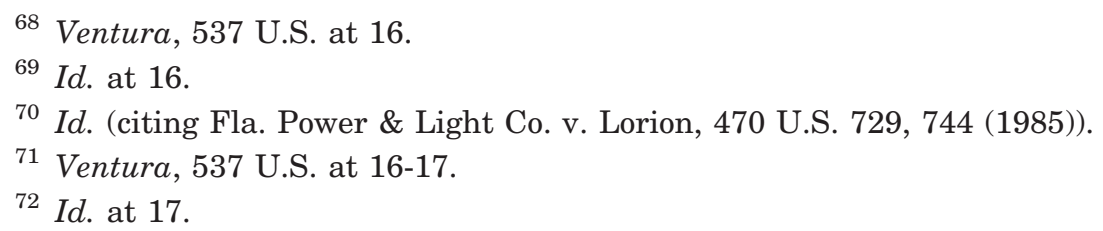


manded with instructions to the court to apply the rule of Ventura. ${ }^{73}$ In Silva-Jacinto v. INS, the court held, in the first instance, that the persecution alleged by the alien was on account of a statutorily protected ground. ${ }^{74}$ Judge Noonan dissented on the ground that such a determination must be made by the agency in the first instance, prior to review by an appellate court. ${ }^{75}$ As no agency decision had been made, remand was required. ${ }^{76}$ The extent of the Ninth Circuit's error in Chen v. INS was broader than either Silva-Jacinto or Ventura itself. $^{77}$ In that case, the agency held that a Chinese alien could not establish his eligibility for asylum because he was not credible, and thus did not reach the merits of the application for relief. ${ }^{78}$ The court reversed the credibility determination, and then went on to hold that the applicant established his eligibility for asylum and withholding of removal on the merits. ${ }^{79}$ The court justified this abrogation of administrative primacy on the ground that "we generally 'do not remand a matter to the BIA if, on the record before us, it is clear that we would be compelled to reverse its decision if it had decided the matter against the applicant.'. . . [A] review of the complete administrative record before us allows us to properly evaluate Chen's claim for relief." 80

Four years later, the Supreme Court was required to revisit its decision in Ventura, in a case again arising from the Ninth Circuit. Michelle Thomas and members of her family, all white South Africans, applied for asylum in the United States. ${ }^{81}$ Both the Board and an immigration judge denied their applications, holding that any harm alleged or feared was not shown to be on account of a statutorily protected ground, specifically, race or political opinion. ${ }^{82}$ The Ninth Circuit explicitly noted that the agency did not address the issue of whether the Thomases could establish eligibility based on their membership in a particular social group, but nonetheless reversed the agency on that issue, holding that the petitioners did establish that the harm alleged was on account of their membership in a particular social group, their family. ${ }^{83}$ The court ordered proceedings remanded to the Board solely for a determination of whether the South African

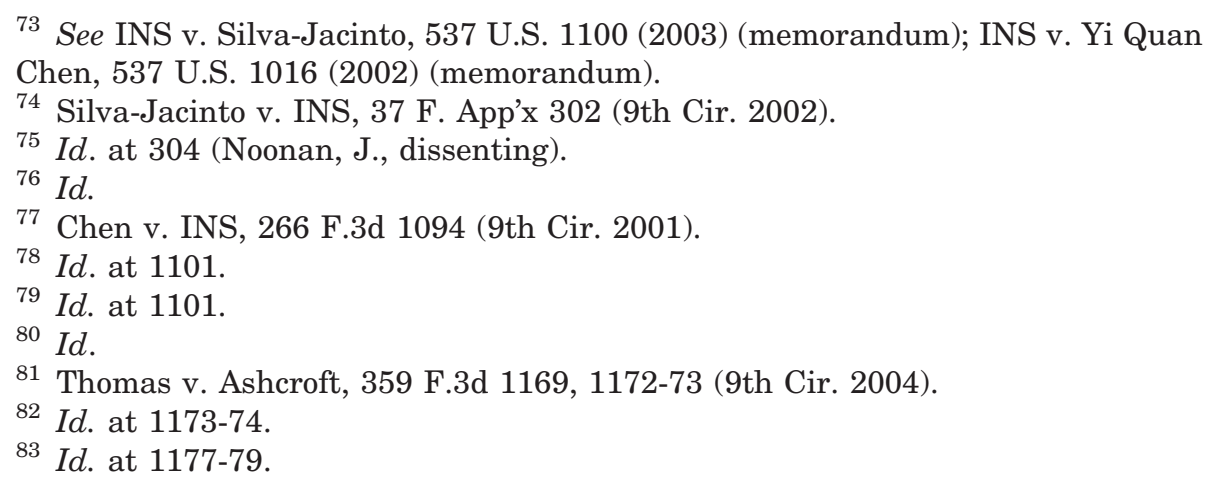


government would be unable or unwilling to protect the Thomases from their purported third-party persecutors. ${ }^{84}$ Judge Fernandez dissented from the majority opinion, writing that he would have denied the petition on its merits, but he did not mention the court's impropriety in reaching the particular social group issue in the first instance. ${ }^{85}$

Rehearing en banc was granted, but the ultimate disposition of the case remained the same. ${ }^{86}$ On rehearing, the court held that: 1) a family may constitute a particular social group within the meaning of the INA; 2 ) the harm suffered by the Thomas family was on account of their family, i.e., on account of their membership in a particular social group, and thus was on account of a statutorily protected ground; and 3) remand was required, pursuant to Ventura, to determine whether the harm alleged and feared rose to the requisite level of severity to constitute persecution, as that term is contemplated by the INA. ${ }^{87}$ Judges Rymer, O'Scannlain, Kleinfeld, and Bea dissented from the en banc decision. The dissenters would have remanded the determination of whether the Thomas family constitutes a particular social group to the Board consistent with the requirements of Ventura. ${ }^{88}$

The Ninth Circuit was again summarily reversed, and in unequivocal language: "The Ninth Circuit's failure to remand is legally erroneous, and that error is 'obvious in light of Ventura,' itself a summary reversal." 89 Having recounted the facts of the Thomas case and its prior holding in Ventura, the Supreme Court held:

We must reach the same conclusion in the present case. The agency has not yet considered whether [the alien's] family presents the kind of 'kinship ties' that constitute a particular social group. The matter requires determining the facts and deciding whether the facts as found fall within a statutory term. ... We can find no special circumstances here that might have justified the Ninth Circuit's determination of the matter in the first instance. Thus, as in Ventura, the Court of Appeals should have applied the "ordinary 'remand' rule."90

In the wake of this case, two other petitions raising particular social group issues were summarily reversed and remanded for proceedings

\footnotetext{
${ }^{84}$ Id. at 1180.

85 See generally id. at 1180 (Fernandez, J., dissenting).

86 Thomas v. Gonzales, 409 F.3d 1177 (9th Cir. 2005) (en banc).

87 See id. at 1187-89.

88 Id. at 1189-93 (Rymer, J., dissenting).

89 Thomas, 547 U.S. 183, 185 (2006).

${ }^{90}$ Id. at $186-87$.
} 
consistent with the Thomas decision. ${ }^{91}$ In Tchoukhrova v. Gonzales, the Ninth Circuit determined, consistent with the immigration judge, that disabled children in Russia constitute a particular social group. ${ }^{92}$ Remand was required, however, because the Board did not explicitly address the issue, affirming the immigration judge's ultimate denial of the application for asylum on the ground that the harm alleged and feared did not rise to the level of persecution. ${ }^{93}$ In Gao v. Gonzales, the Second Circuit impermissibly determined, in the first instance, that women sold into marriage contracts constitute a particular social group. ${ }^{94}$

Finally, in its October 2008 term, the Supreme Court issued its latest decision in the Ventura line-Negusie v. Holder. ${ }^{95}$ Negusie, an Eritrean, filed a petition for review of the agency's determination that he was ineligible for asylum and withholding of removal on account of the "persecutor bar." 96 He had worked as a jailer in a prison where the prisoners were routinely persecuted, but he averred that he did not participate directly in such acts. ${ }^{97}$ Noting the Supreme Court's prior decision in Fedorenko $v$. United States,${ }^{98}$ as had the agency before it, the Fifth Circuit deemed irrelevant the question of whether Negusie was coerced to participate or whether he shared the opinions of his coworkers. ${ }^{99}$ On the record before it, the court held that the evidence did not compel the finding, contrary to that reached by the agency, that Negusie did not assist in the persecution of prisoners. ${ }^{100}$

The Supreme Court reversed and remanded to the Fifth Circuit with instructions to remand to the Board for further proceedings.(insert footnote 94a here). The Court held that Fedorenko did not control the outcome of Negusie's case, as the statutory schemes at issue in the respective cases were distinct in material ways, including in the purposes and rationales behind their enactment. ${ }^{101}$ The Board had rendered its decision under the false assumption that Fedorenko did control the disposition of the case, and thus had not yet exercised its authority to interpret the statute in the first instance free of er-

91 See Gonzales v. Tchoukhrova, 549 U.S. 801 (2006) (memorandum); Keisler v. Hong Yin Gao, 552 U.S. 801 (2007) (memorandum).

92 See Tchoukhrova v. Gonzales, 404 F.3d 1181, 1187 (9th Cir. 2005).

${ }^{93} \mathrm{Id}$.

${ }^{94}$ Gao v. Gonzales, 440 F.3d 62 (2d Cir. 2006).

95 Negusie v. Holder, 129 S. Ct. 1159 (2009).

96 Negusie v. Gonzales, 231 F. App'x 325 (5th Cir. 2007); see INA $\S \S 208(b)(2)(A)(i), 241(b)(3)(B)(i), 8$ U.S.C. $\S \S 1158(b)(2)(A)(i), 1231(b)(3)(B)(i)$.

97 Negusie, 231 F. App'x at 326.

98 Fedorenko v. United States, 449 U.S. 490, 512 (1981).

99 Negusie, 231 F. App'x at 326.

100 Id.

101 Negusie, 129 S. Ct. at 1164-66. 
ror; ${ }^{102}$ remand was required to allow the Board to interpret the scope and content of the "persecutor bar" provision in the first instance. ${ }^{103}$ Justifying this outcome, especially in light of a dissent that would have rendered an interpretation of this provision in the first instance, ${ }^{104}$ the Court noted that the "remand rule exists, in part, because ambiguities in statutes within an agency's jurisdiction to administer are delegations of authority to the agency to fill the statutory gap in reasonable fashion. Filling these gaps . . . involves difficult policy choices that agencies are better equipped to make than courts." 105

As a collection, what should these cases and their statement of the "ordinary remand rule" be taken to stand for? Do these cases establish a bright line rule of the sort Judge Friendly found missing in Chenery and its progeny? The appeal to science must fail, as the question of remand remains more art than mechanics, but at least three principles are apparent, largely mirroring those noted by Friendly in his distillation of Chenery.

First, the "reversal of the agency on a dispositive issue such as credibility may bring into play issues of eligibility or discretion not yet addressed by the agency," necessitating remand for further proceedings. ${ }^{106}$ Remand would seem to be not only the most appropriate recourse, but the necessary one in immigration cases, notwithstanding any "clarity" the court could perceive in the evidence of record. As now-Board member John Guendelsberger wrote of Ventura, "[t]he court ... reached its determination that remand was required for an unresolved question of fact independently of any examination of the strength of the factual record before it. . . . [Thus, e]ven if the court regards the evidence of record as so one-sided as to make the result on remand a foregone conclusion, the court should remand to the agency rather than proceed to evaluate whether reasonable factfinders could reach different conclusions based on the evidence."107 Accordingly, if a factual issue has not been addressed by the Board in the first instance, and factual issues in the immigration context include many eligibility determinations for relief and protection under the INA, the matter must be remanded notwithstanding the fact that the court perceives the "correct" resolution of the issue. This may or may not be the case

\footnotetext{
102 Id. at $1166-67$.

103 Id. at 1167-68.

104 See id. at 1170-76 (Stevens, J., concurring in part, dissenting in part).

105 Id. at 1167 (majority opinion).

106 John W. Guendelsberger, Judicial Deference to Agency Decisions in Removal Proceedings in Light of INS v. Ventura, 18 Geo. ImMigr. L.J. 605, 635 (2004).

107 Id. at 636 .
} 
when resolution of one issue properly before the court gives rise to a new purely legal or constitutional claim that has not yet been addressed by the agency. There may be instances that fall within the "rare circumstances" language, but these would have to be addressed on a case-by-case basis. It is worth noting that remand would still be the presumption even if the unresolved issue is legal or constitutional in character, so long as the Board has jurisdiction to address the issue on remand. Reviewing cases in the immediate aftermath of Ventura, Guendelsberger observed that "[r]ather than decide the issue ahead of the agency, some courts simply express their view that the respondent appears to be eligible and remand to permit the agency to make the decision. This procedure likely accomplishes the desired result without raising any questions of compliance with the Ventura remand requirement."108

Second, remand may be required in circumstances where the agency has addressed the relevant issue, but where it "committed legal or factual error in reaching its conclusion." ${ }^{109}$ Errors in this category may require remand, or they may fall within the "rare circumstances" exception. For instance, if the agency somehow erred in determining eligibility for asylum, and the court concludes that the record compels the conclusion that the alien did establish eligibility for asylum, remand would be required only insofar as the agency would have to render an ultimate discretionary determination on whether asylum should be granted. Harkening back to pre-Ventura cases, if the agency committed a legal error in determining eligibility, but otherwise denied relief in the exercise of discretion and would do so regardless of technical statutory eligibility, remand should be foregone as the agency discretionary decision is determinative notwithstanding the legal errors. To the contrary, if the agency applies an incorrect legal standard or otherwise makes a legal error in determining eligibility, but has expressed no opinion regarding whether relief would be granted in the exercise of discretion, remand would be the appropriate course of action.

Finally, "[r]emand for further agency review may also be needed when a court finds analysis too terse, elliptical, or inadequate to permit meaningful evaluation of the agency's reasoning. In such a situation, rather than substitute the court's own analysis or guess at what the Board's reasoning must have been," remand for further clarification is required. ${ }^{110}$ This assertion is rooted in Chenery's observation that agency action can be sustained only on the grounds upon which the agency itself based its initial decision, and if these grounds

\footnotetext{
108 Id. at 638 .

109 Id. at 635 .

110 Id. at 641.
} 
are unclear, the proceeding must be remanded even if the result the agency reached appears to be correct or otherwise sustainable. ${ }^{111}$ In essence, the agency must be given the opportunity to clarify its rationale prior to having its action judged on review before the appellate court.

The Seventh Circuit gave its own exposition of Ventura in its 2004 decision in Ghebremedhin v. Ashcroft.$^{112}$ In its initial panel decision, the court determined that a finding of persecution was compelled, and entered an order remanding the case to the Board to enter an order granting the applicant asylum. ${ }^{113}$ The government petitioned for panel rehearing, "arguing that [the court's] decision to remand the case with instructions to enter an order granting asylum" contravened Ventura's ordinary remand rule. ${ }^{114}$ The government based its argument on two contentions connected to the Supreme Court's reasoning in Ventura: 1) "that once an agency error is identified, a court of appeals should remand a case for additional investigation or explanation"; and 2) "appellate courts should not decide issues when an agency has not considered them." 115 The court disagreed with the government's contention that any error necessitates remand: "[W]e do not agree that Ventura stands for the broad proposition that a court of appeals must remand a case for additional investigation or explanation once an error is identified. . . . We are well-within our authority to reverse the IJ's eligibility determination if manifestly contrary to law, and our decision to do so in no way disregards the agency's expertise and role as front-line evaluator of evidence. ... Moreover, if the record evidence compels the result that we have reached, then no alternative determination is possible."116 The court did, however, agree that its order directing that asylum be granted overstepped the permissible bounds of its authority, as that was a decision confined to the Attorney General's discretion. ${ }^{117}$ Accordingly, the petition for rehearing was granted, and the opinion modified to remove the directive to grant asylum.

111 SEC v. Chenery, 318 U.S. 80, 95 (1943); SEC v. Chenery, 332 U.S. 194, 196 (1947); see Friendly, supra note 3, at 222.

112 Ghebremedhin v. Ashcroft, 392 F.3d 241 (7th Cir. 2004) (order).

113 Ghebremedhin v. Ashcroft, 385 F.3d 1116, 1120 (7th Cir. 2004).

114 Ghebremedhin, 392 F.3d at 242.

115 Id. at 243.

116 Id.

117 Id. at 244 ("The Attorney General does not contest that Ghebremedhin is statutorily eligible for asylum, but instead argues that the panel essentially exercised a purely administrative function by remanding with instructions to enter an order granting asylum. We agree that the power to grant asylum is vested solely in the hands of the Attorney General, and that even if an alien is otherwise eligible, the Attorney General is empowered by statute to deny relief."). 
In the end, the Ventura line of cases is akin to its Chenery predecessors, insofar as both drew in broad strokes while vesting considerable discretion in the courts of appeals to remand or consider and decide the issue in the first instance. Ventura explicitly and unequivocally "recognizes the primary role of the Board . . . in interpreting the immigration law in removal proceedings. [It] makes clear that the agency should determine whether the evidence of record meets the relevant legal standards before the court applies the substantial evidence test to the record. Likewise, the courts should permit the agency to address unresolved issues involving interpretation of the immigration law before examining whether the Board's interpretation is within the leeway permitted" by the governing standards of administrative law. ${ }^{118}$ Nonetheless, the decision also

[L] eaves considerable room for disagreement as to when remand for further agency review is required. What appears evident is that the courts retain a large measure of discretion in determining, on a case by case basis, whether factual investigation or explanation from the agency should be requested when there are concerns with the factual or analytical underpinnings of the agency decision. ${ }^{119}$

To what extent the courts of appeals have exercised their discretion to hold immigration cases rather than remand to the agency, and whether these dispositions are a legitimate exercise of the appellate function or a transgression of the ordinary remand rule, is the subject of the following section.

\section{III. “FUTILITY OF REMAND” JURISPRUDENCE POST-VENTURA}

Since Ventura was decided in 2002, several courts of appeals have held that, in situations where remand to the Board for further proceedings would be futile, the court may decide an issue in the first instance, notwithstanding the fact that the agency may not have addressed the issue in its underlying decision, or the agency decision was somehow erroneous. In effect, the courts have attempted to develop a jurisprudence of the "rare circumstances" exception to the ordinary remand rule. The intent of this section is to explore these decisions, while the subsequent section will address whether these decisions are in any meaningful way about the courts' remand authority and whether, if these decisions do implicate Ventura, the courts have acted permissibly in declining to remand. In the context of "futility jurispru-

\footnotetext{
118 Guendelsberger, supra note 106, at 649.

119 Id. at 644.
} 
dence," the Second Circuit's line of precedent is by far the most developed and will be the focus of this section. Nonetheless, at least seven other courts of appeals have held that remand to the Board would be futile in certain circumstances, and those decisions will also be addressed.

\section{A. Futility in the Second Circuit}

The Second Circuit's futility jurisprudence is largely grounded in a series of decisions issued in early 2006, addressing agency adverse credibility determinations. In Cao He Lin v. U.S. Department of Justice, the immigration judge, affirmed by the Board, denied a Chinese alien's application for asylum based on the determination that the alien was not credible in the presentation of his claim. ${ }^{120}$ In reaching its decision in the case, the Second Circuit undertook an extensive review of its scope of review regarding the circumstances where it would be required to remand for further proceedings. Although "serious legal errors ... will ordinarily require vacatur and remand for a new assessment of the evidence and/or a new hearing[,] . . . [o]ur cases implicitly recognize ... that not every minor error requires a remand."121 For instance, the court averred that it would not be required to remand if it had discerned error in one aspect of the agency decision, but the agency had also based its decision on a second, independently dispositive, and error free finding. ${ }^{122}$ Additionally, the court contended that it was "not required to remand where there is no realistic possibility that, absent the errors, the IJ or BIA would have reached a different conclusion." ${ }^{123}$ For this proposition, the court relied explicitly on preVentura case law and Supreme Court precedent, including Chenery, pertaining to administrative law in general. ${ }^{124}$ In these cases, the court found support for at least two principles that "would support affirming despite legal error and despite the policy of allowing the administrative adjudicator to assess the impact of identified legal error on its credibility and sufficiency findings. ..."125 Remand may not be required if the agency's "reliance on an erroneous aspect of its reasoning is so tangential that there is no realistic possibility that the outcome would be different on remand."126 Secondly, the court "believe[d] that remand should not be required where-notwithstanding admitted errors-overwhelming evidence supporting the administrative adjudi-

\footnotetext{
120 Cao He Ling v. U.S. Dep’t of Justice, 428 F.3d 391, 394 (2d Cir. 2005).

121 Id. at 401.

122 Id.

123 Id.

124 See id. at 401-02.

125 Id. at 402.

126 Id.
} 
cator's findings makes it clear that the same decision would have been reached in the absence of the errors." ${ }^{127}$ Based on these principles, the court then established a rough scheme concerning outcomes in different situations: 1) the court will "defer to the IJ's fact-finding and affirm when the fact-finding is based on specific and cogent reasons not infected by legal error," 2) it will "remand where identified errors leave [it] in doubt whether the IJ would have reached the same result absent the errors," 3) it will "affirm, despite IJ errors, when [it] can confidently predict that the IJ would necessarily reach the same result absent errors," and 4) it will "grant the petition only in those extremely rare instances where substantial evidence does not exist to support the IJ's decision." ${ }^{28}$ Applying those principles to Cao He Lin's case, the Court held "that the erroneous aspects of the IJ's reasoning are not tangential to the findings she made and that the evidence supporting her findings is not so overwhelming that it is clear she would reach the same results on remand." 129 Thus, remand was necessary.

The Second Circuit revisited this reasoning shortly thereafter in the case of Xiao Ji Chen, another Chinese asylum seeker. ${ }^{130}$ The agency decision at issue was again a credibility determination, as both the Board and the immigration judge held that Chen failed to credibly establish his eligibility for relief or protection under the INA. The Second Circuit noted that an agency credibility determination must be supported by substantial evidence in the record, ${ }^{131}$ but also wrote that it "may affirm [such a finding] even when the IJ's reasoning is deficient in certain respects, provided that despite any errors-considered in the context of the IJ's entire analysis-we can state with confidence that the same decision would be made if we were to remand." $132 \mathrm{Al}$ though referring to its prior decision in $\mathrm{CaO} \mathrm{He} \mathrm{Lin}$ and the circumstances that panel discerned in which remand to the agency would not be warranted, the Xiao Ji Chen panel held that, as the ultimate finding and disposition in $\mathrm{Cao} \mathrm{He} \mathrm{Lin}$ was that the agency decision could not be sustained, thus necessitating a remand, "by also identifying potential circumstances where a remand would not have been required, [that] panel was of course offering dicta." ${ }^{133}$ Accordingly, the decision

\footnotetext{
127 Id.

128 Id. at 395 .

129 Id. at 406.

130 Xiao Ji Chen v. U.S. Dep't of Justice, 434 F.3d 144 (2d Cir. 2006), reh'g granted on other grounds Xiao Ji Chen v. U.S. Dep't of Justice, 471 F.3d 315 (2d Cir. 2006) (all citations are to the opinion issued on rehearing).

131 See Immigration and Nationality Act $\S 242(\mathrm{~b})(4)(B), 8$ U.S.C. $\S 1252(\mathrm{~b})(4)(B)$ ("the administrative findings of fact are conclusive unless any reasonable adjudicator would be compelled to conclude to the contrary").

${ }^{132}$ Xiao Ji Chen, 471 F.3d at 335 (citing Cao He Lin, 428 F.3d at 401-02).

133 Id. at 338 .
} 
in $\mathrm{Cao} \mathrm{He}$ Lin did not establish any binding precedent regarding the circumstances as to when a remand would not be required despite errors in the agency decision. ${ }^{134}$ Nonetheless, Xiao Ji Chen recognized that the court in Cao He Lin did ascertain the proper "overarching test for deeming a remand futile": "when the reviewing court can "confidently predict' that the agency would reach the same decision absent the errors that were made." 135 This exercise is fraught with subjectivity and discretion:

The strength of the error-free portions of an IJ's ultimate finding that will permit a panel to state with confidence that a remand would be futile cannot be precisely quantified. Whether the evidence supporting the error-free findings is characterized as "overwhelming," "significant," "highly persuasive," or some other comparable wording is more a matter of linguistics than law. If the reviewing court undertakes to determine whether remand would be futile, it should assess the entire record and determine whether, based on the strength of the evidence supporting the error-free findings and the significance of those findings, it is clear that the agency would adhere to its decision were the petition remanded. ${ }^{136}$

Nonetheless, it is within the court's legitimate authority not only to remand when that recourse is appropriate, but also to affirm the agency's determination "despite error, where that analysis is otherwise supported by substantial evidence and we can state with confidence that the same decision would be made on remand." ${ }^{37}$ In Xiao Ji Chen's case, although the immigration judge's credibility determination did contain errors, the ultimate finding that the applicant failed to credibly carry his burdens in establishing eligibility for relief and protection under the INA was supported by substantial evidence in the record, negating any need for remand to address the noted errors. ${ }^{138}$

The court reached the same conclusion in two other cases decided that spring. In Qyteza v. Gonzales, the court denied a petition for review where, "notwithstanding our recognition of error in the IJ's decision, we conclude that the ... denial of petitioners' asylum application was supported by substantial evidence and, despite error, 'we can state with confidence that the IJ would adhere to [her] decision were

\footnotetext{
134 Id.

135 Id. at 339 (citing Cao He Lin, 428 F.3d at 395).

136 Id. at 339 .

137 Id.

138 Id.
} 
the petition remanded."139 Similarly, in Lin v. Gonzales, the court held that "[d] espite the errors made by the IJ in this case, the adverse credibility determination is supported by substantial evidence. . . As we have no doubt that the IJ would have reached the same conclusions without reliance on the erroneous findings, we therefore deny Lin's petition for review." 140

The court nonetheless revisited its prior decisions in $\mathrm{CaO} \mathrm{He}$ Lin and Xiao Ji Chen in a pair of Calabresi decisions issued at the end of June 2006, which sought to harmonize the superficially disparate analysis offered by those cases. ${ }^{141}$ In Li Hua Lin, the court began its assessment of futility by noting the deferential compelling evidence standard pursuant to which the courts of appeals review the agency's factual findings under the INA. ${ }^{142}$ Pursuant to that deferential standard, "where an IJ's errors are relatively minor in light of the record as a whole, the understandable inclination is to assume the errors are 'harmless' and deny review, just as we would affirm a district court judgment tinged with errors that do not affect the ultimate outcome of the proceeding." 143 Nonetheless, the courts of appeals must also be "mindful ... that 'a judicial judgment cannot be made to do service for an administrative judgment," 144 and "[i]t is precisely because factfinding in both the asylum and the withholding contexts is expressly committed to the discretion of the Executive Office for Immigration Review ("EOIR") that, when those findings rely upon legal errors, the appropriate remedy is generally to vacate those findings and remand to the BIA for reconsideration of the applicant's claim." ${ }^{145}$ Although these requirements do not necessarily impel the court to chart a dangerous path between Scylla and Charybdis, its jurisprudence nonetheless "remains on a continuing course of reconciliation between the twin commands neither to disturb substantially supported factual determinations nor to let stand determinations that rely, in whole or in part, on legal error." 146

Calabresi recounted the trajectories of the court's decisions in Cao He Lin and Xiao Ji Chen, noting the slight or superficial differences in the approach to the question of remands presented by each

\footnotetext{
139 Qyteza v. Gonzales, 437 F.3d 224, 228 (2d Cir. 2006) (per curiam) (citation omitted).

$140 \mathrm{Tu}$ Lin v. Gonzales, 446 F.3d 395, 403 (2d Cir. 2006).

141 Li Hua Lin v. U.S. Dep't of Justice, 453 F.3d 99 (2d Cir. 2006); Li Zu Guan v. INS, 453 F.3d 129 (2d Cir. 2006).

${ }^{142} \mathrm{Li}$ Hua Lin, 453 F.3d at 106 (citing INA $\S 242(\mathrm{~b})(4)(\mathrm{B}), 8$ U.S.C. $\S 1252(\mathrm{~b})(4)(\mathrm{B}))$.

143 Id. (citing United States v. Dominguez Benitez, 542 U.S. 74, 81 (2004)).

144 Id. (citing Chenery, 318 U.S. 80, 88 (1943)).

145 Id.

146 Id.
} 
case. ${ }^{147}$ Taken together, however, the panel harmonized the prior decisions by taking them to establish, jointly, that remand to the Board would be futile in at least three distinct circumstances: a) when the IJ articulates an alternative and sufficient basis for her determination; b) when her reliance on the erroneous aspect of her reasoning is substantially tangential to her non-erroneous findings; or c) when overwhelming evidence in the record makes clear that the same decision is inevitable on remand, or, in short, whenever the reviewing panel is confident that the agency would reach the same result upon a reconsideration cleansed of errors. ${ }^{148}$ Thus, the court's prior case law established a non-exhaustive and non-exclusive list of circumstances in which the court could decline to remand a matter to the agency for further proceedings notwithstanding the presence of errors in the decision on review. In Li Hua Lin, the petition was granted, as the Second Circuit could not "be confident that the agency would reach the same result on remand absent" the identified errors. ${ }^{149}$

$\mathrm{Li} Z \mathrm{Zu}$ Guan, written by Calabresi as well, was issued the following day. ${ }^{150}$ The importance of this decision in the evolving jurisprudence of futility lies with its statement of the interplay between the futility of remand and the deferential compelling evidence standard of review. The court again noted that the operative question in determining whether remand would be futile "is whether [it] can predict the same result in the absence of errors[.]" 151 To that end, the court held that "where errors have been found in the EOIR decision, a residue of substantial evidence in support of the agency's result is a necessary, but not sufficient, condition for denial of review." 152 The question becomes not simply whether the agency decision can be supported on the record, absent the errors, but whether the court can predict that the agency would have reached the same conclusion in an error-free proceeding, or would reach the same conclusion on remand after the identification of the relevant errors: "to deny review in the face of EOIR errors, a court must have confidence that an error-free proceeding would yield the same result. The existence of substantial evidence supporting that result, without more, is not enough to give rise to such confidence." 153 This assertion will be examined more closely in the subsequent section, as it is incorrect as a matter of law, resting, as it does, on a profound misunderstanding of the courts' appropriate standard of review.

147 Id. at $106-07$.

148 Id.

149 Id. at 111.

${ }^{150} \mathrm{Li} \mathrm{Zu} \mathrm{Guan} \mathrm{v.} \mathrm{INS,} 453$ F.3d 129 (2d Cir. 2006).

151 Id. at 137.

152 Id. at $137-38$.

153 Id. at 138. 
Since the Li Hua Lin and $\mathrm{Li} \mathrm{Zu}$ Guan decisions the Second Circuit has issued numerous other decisions addressing the futility of remand, but only those which make a substantial contribution to the evolution or understanding of that principle will be examined here. In Ucelo-Gomez v. Gonzales, the Second Circuit determined that remand was appropriate so as to allow the Board to determine, in the first instance, whether or under what circumstances "affluent Guatemalans" could constitute a particular social group under the INA. ${ }^{154}$ Despite this disposition, the court opined that "[i]f a reviewing court can state with assured confidence (absent agency guidance as to its protectability under the INA) that a group would or would not under any reasonable scenario qualify as a 'particular social group,' it need not remand, and may rule on the issue in the first instance."155 This decision is distinct from those already analyzed insomuch as it sanctions potentially deciding an issue against the government in the first instance, rather than simply discerning whether the agency's determination can otherwise be upheld notwithstanding certain errors in its reasoning. In Hoxhallari v. Gonzales, the court denied a petition for review despite a lack of analysis on the part of the immigration judge regarding whether country conditions in Albania had changed to a sufficient degree to rebut a presumption of persecution, where the court found it clear that there had been a fundamental change that would, on any reading of the evidence, rebut the alien's fear of persecution and thus foreclose his ability to establish eligibility for asylum or withholding of removal. ${ }^{156}$ The decision in Bhanot $v$. Chertoff represents a step toward greater court authority in this area, as the court considered evidence in the first instance in discerning whether remand would be appropriate. ${ }^{157}$ The Board arguably failed to consider an affidavit proffered in conjunction with the alien's motion to reopen and rescind an in absentia order, but the court declined to remand because the affidavit contained only an uncorroborated statement of non-receipt of the hearing notice and contained a significant misstatement of fact. ${ }^{158}$ In such circumstances, the court determined it was clear that consideration of this piece of evidence would not alter the agency's holding. ${ }^{159}$ Finally, in Matadin v. Mukasey, the court determined that remand would not be futile in a case where the agency misallocated the burden of proof between the alien and the government regarding the issue of whether the alien abandoned her lawful permanent resi-

\footnotetext{
${ }^{154}$ Ucelo-Gomez v. Gonzales, 464 F.3d 163 (2d Cir. 2006).

${ }^{155} \mathrm{Id}$. at 170 .

${ }^{156}$ Hoxhallari v. Gonzales, 468 F.3d 179 (2d Cir. 2006).

157 Bhanot v. Chertoff, 474 F.3d 71 (2d Cir. 2007) (per curiam).

${ }^{158} \mathrm{Id}$. at 74 .

${ }^{159} I d$.
} 
dent status. ${ }^{160}$ If the burden was correctly allocated, it was not clear, in the court's opinion, that the agency would reach the same conclusion, i.e., that the lawful permanent resident status would be found abandoned. ${ }^{161}$ Judge Walker concurred in the reasoning of the majority and wrote separately simply to express his opinion that the case was close but, in the final assessment, the correct allocation of the burden may be determinative and result in a different outcome. ${ }^{162}$

As the foregoing review should make clear, the Second Circuit has conceived a robust conception of its authority to address factual and legal issues in the first instance, even without prior resolution by the agency. Whether this conception conflicts with Ventura's ordinary remand rule is an inquiry that must wait until the following section. The remainder of the instant section is concerned with those other courts of appeals that have held remand may be futile in certain cases.

\section{B. Futility in Other Federal Courts of Appeals}

In addition to the Second Circuit, the First, Fourth, Fifth, Sixth, Seventh, Ninth, and Eleventh Circuits have decided cases, postVentura, in which the court has held remand would be futile and thus decided a matter in the first instance. This jurisprudence, in comparison with that of the Second Circuit, is nascent and confined for the most part to solitary cases. Nonetheless, these cases are revealing concerning the scope and extent of the court's authority as conceived in the respective circuits, and may well be indicative of a broader movement in these courts to develop a coherent and cohesive body of futility precedent akin to that of the Second Circuit.

\section{The First Circuit}

In Sok v. Mukasey, the First Circuit hinted that remand may in certain cases be futile, but nonetheless remanded to the agency for further proceedings as such futility was not evident in the facts of that case. ${ }^{163}$ An immigration judge determined that Ms. Sok could not establish her eligibility for asylum, as she failed to establish past persecution in Cambodia on account of her political opinion, and any claim of a well-founded fear of persecution was unsupported by the relevant State Department Country Reports and undercut by the fact that her children remained in Cambodia, unharmed. ${ }^{164}$ The First Circuit held that the agency's finding on the issue of past persecution was not sup-

\footnotetext{
160 Matadin v. Mukasey, 546 F.3d 85 (2d Cir. 2008).

161 Id. at 91-93.

162 Id. at 93-95 (Walker, J., concurring).

163 Sok v. Mukasey, 526 F.3d 48 (1st Cir. 2008).

164 Id. at 51-52.
} 
ported by the record, and thus could not be sustained. ${ }^{165}$ Because the past persecution determination was unsustainable, the court noted that it would be difficult to review the agency's determination regarding the alien's fear of future persecution, as a presumption of persecution would be warranted if the alien could establish past persecution. ${ }^{166}$ Additionally, even if the presumption did operate in Sok's case, the government would have the opportunity to rebut that presumption with evidence undercutting the claim of future persecution. ${ }^{167}$

The First Circuit "acknowledged that there are some cases in which the agency's failure to properly analyze past persecution is harmless error because the record makes it abundantly clear that the petitioner will not likely suffer future persecution if sent back to her home country." 168 When such circumstances are presented, the court concluded that it could "affirm the agency's decision despite its flaws because the petitioner's claim is per se destined to fail, and to remand for further proceedings would therefore be futile." ${ }^{169}$ Sok's case did not present such circumstances, however, as the Country Reports were not unequivocal concerning the possibility of future persecution on account of her political opinion, and the fact that her children remained in Cambodia unharmed, without additional analysis, did not necessarily undercut her claim. ${ }^{170}$ As the record was not clear that Sok would not suffer future persecution in Cambodia, making the allocation of the burden of rebutting the presumption of a well-founded fear important, proceedings were by necessity remanded to the Board for further consideration of both Sok's claim of past persecution and fear of future persecution. ${ }^{171}$

\section{The Fourth Circuit}

The First Circuit's Sok decision represents the court's understandable reticence to reach a factual issue in the absence of agency consideration of that issue in the first instance. In Hussain v. Gonzales, the Fourth Circuit addressed and resolved a legal issue despite the fact that the Board had not yet had occasion to rule on that question. ${ }^{172}$ Hussain was ordered removed in absentia by an immigration judge yet, over two years later, he filed a motion to reopen seeking to

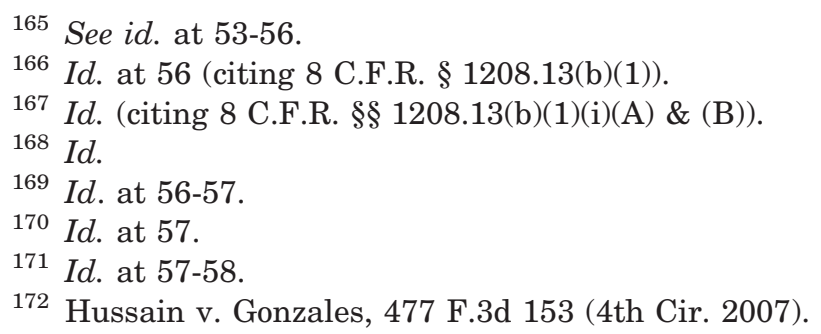


rescind the in absentia order. The immigration judge denied the motion, agreeing with the argument of DHS that the motion was untimely and failed to establish exceptional circumstances regarding Hussain's failure to appear. Hussain appealed to the Board and, while that appeal was pending, filed a motion to remand alleging eligibility to adjust his status. The Board dismissed the appeal and ostensibly denied the motion to remand, although its language on this point was equivocal. Hussain filed a petition for review with the Fourth Circuit, where he solely challenged the Board's disposition of his motion to remand proceedings. ${ }^{173}$

The Fourth Circuit held that there was no language in the Board's decision that could be read to have addressed or disposed of the motion to remand, and thus that "the Board's order neglected to dispose" of that motion. ${ }^{174}$ Nonetheless, the court held that remand was not necessary, despite the fact that the Board had not addressed the motion to remand and the arguments raised therein, because Hussain was statutorily ineligible for adjustment of status on account of the fact that he was not admissible to the United States-his presence in the United States without having been admitted or paroled constituted a ground of inadmissibility disqualifying him from adjustment of status under section 245(a) of the INA. ${ }^{175}$ Regarding the Supreme Court's decisions in Ventura and Thomas, the Fourth Circuit reasoned that those decisions dealt with factual issues rather than the legal claim raised by Hussain. According to the majority, Hussain's legal issue did not present circumstances where a remand would serve any useful purpose: "Simply stated, Hussain is ineligible for the relief he seeks because he is unable to establish a prima facie case for adjustment of status. As such, to remand this matter to the Board for further consideration would serve no useful purpose."176 Accordingly, the "rare circumstances" exception was found to be applicable, especially in light of the delay remand would entail and the inevitability of the identical disposition of Hussain's claim even if proceedings were remanded. ${ }^{177}$

Judge Hamilton dissented, raising two issues connected to the Chenery and Ventura line of cases. ${ }^{178}$ First, Judge Hamilton would have remanded proceedings to the Board for a clarifying order addressing whether or why the Board denied the motion to remand filed

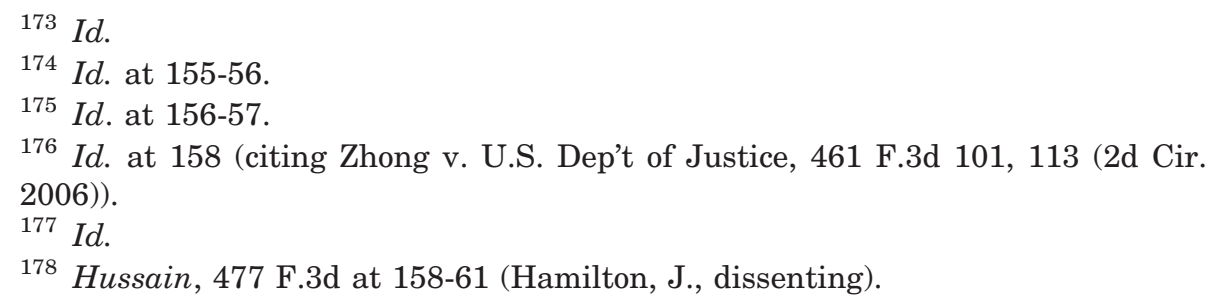


by Hussain. ${ }^{179}$ Second, remand would be necessary without a Board decision addressing the motion to remand, as the Board is charged with the primary responsibility of disposing of such motions. Judge Hamilton found the majority's distinction between factual issues, which would necessitate remand, and legal issues, which the Court could conceivably address in the first instance, unavailing, as both Ventura and Thomas raised factual and legal issues pertaining to eligibility for relief under the INA. ${ }^{180}$ Likewise, whether Hussain could establish eligibility for adjustment of status involved threshold factual issues which the Board had not resolved, not simply legal issues regarding whether undisputed facts established statutory eligibility. ${ }^{181}$ Thus, for Judge Hamilton, there was "nothing in the circumstances of [Hussain's] case which suggest that [it] presents 'rare circumstances' justifying exception from the ordinary remand rule." 182

\section{The Fifth Circuit}

The two main cases arising out of the Fifth Circuit involve both legal and factual questions, highlighting the broad reach the courts have given Ventura's "rare circumstances" exception. In Yu Zhao v. Gonzales, a Chinese alien applied for asylum in the United States based on persecution and a fear of persecution attributable to his practice of Falun Gong. ${ }^{183}$ This application was denied by the agency, on the grounds that Zhao could not establish past persecution or a wellfounded fear of persecution on account of one of the five statutorily protected grounds. Subsequent to the Board's decision dismissing his appeal, Zhao filed a motion to reconsider, seeking to introduce new evidence of his claim, but this motion was denied. Zhao challenged both decisions before the Fifth Circuit.

The Fifth Circuit held that the Board abused its discretion in denying Zhao's motion, to the extent that his motion could be construed as a motion to reopen to submit new and additional evidence of his asylum eligibility; specifically, evidence pertaining to the treatment of Falun Gong practitioners in China. ${ }^{184}$ The court additionally held that, although the Board properly determined that Zhao failed to establish past persecution, it erred in finding that the evidence did not support a well-founded fear of persecution. ${ }^{185}$ In making this determination, however, the court declined to reverse the well-founded fear

\footnotetext{
179 Id. at 159 .

180 Id. at $160-61$.

181 Id. at 161.

${ }^{182}$ Id. (citing INS v. Ventura, 537 U.S. 12, 16 (2002) (per curiam).

$183 \mathrm{Yu}$ Zhao v. Gonzales, 404 F.3d 295 (5th Cir. 2005).

184 Id. at 304-05.

${ }^{185}$ Id. at $307-10$.
} 
determination and remand for further proceedings, but rather found that the totality of the evidence compelled that determination and that there were no discretionary grounds that would argue against a grant of asylum. ${ }^{186}$ Thus, the court granted Zhao's application for asylum without offering the Board the opportunity to address his claim in light of the additional evidence or the errors identified by the court. It reasoned, in so doing, that the Board had already had the opportunity to address the asylum claim and thus that it was not usurping the BIA's authority to render a decision in the first instance, and that, in any event, the language of Ventura was precatory. ${ }^{187}$ "We cautiously conclude that this case exhibits the narrow set of circumstances that requires no remand." 188

Judge Garza dissented, disagreeing with the majority's assertion that the case exhibited those narrow circumstances where remand could be dispensed with under Ventura.$^{189}$ Although the Board had addressed Zhao's asylum claim in the administrative proceedings, it had not been afforded the opportunity to do so in light of the additional evidence proffered with the motion to reconsider, or in light of the identified errors in its earlier decision. ${ }^{190}$ In Judge Garza's view, then, the proper course would be to remand to the Board for further investigation and explanation concerning the merits of Zhao's claim.

Unlike the factual resolution at issue in $Y u$ Zhao, the recently decided case Dale $v$. Holder involved the resolution of a purely legal question implicating state law, an area outside the Board's recognized expertise. ${ }^{191}$ The alien in that case was charged with being removable as an aggravated felon convicted of a crime of violence. He was convicted under N.Y. Penal Law $§ 120.10$, pertaining to assault, yet his conviction would only constitute an aggravated felony if his conviction was pursuant to the first two subsections of that statute. ${ }^{192}$ After vari-

\footnotetext{
186 Id. at 310.

187 Id. at 311.

188 Id.

189 Yu Zhao, 404 F.3d at 311 (Garza, J., dissenting).

$190 \mathrm{Id}$.

191 Dale v. Holder, 610 F.3d 294 (5th Cir. 2010).

192 "A person is guilty of assault in the first degree when: 1 . With intent to cause serious physical injury to another person, he causes such injury to such person or to a third person by means of a deadly weapon or a dangerous instrument; or 2 . With intent to disfigure another person seriously and permanently, or to destroy, amputate or disable permanently a member or organ of his body, he causes such injury to such person or to a third person; or 3. Under circumstances evincing a depraved indifference to human life, he recklessly engages in conduct which creates a grave risk of death to another person, and thereby causes serious physical injury to another person; or 4. In the course of and in furtherance of the commission or attempted commission of a felony or of immediate flight therefrom, he, or
} 
ous levels of proceedings, both administrative and before the Fifth Circuit, the Board determined that his conviction must have been pursuant to one of the first two subsections of the statute, as only the first two subsections contained the necessary mens rea requirement that would support his plea to the "attempt" offense. ${ }^{193}$ Before the Fifth Circuit, the government primarily argued that the court lacked jurisdiction over the petition because Dale failed to administratively exhaust his claim that New York law permitted pleas to the last two subsections of the statute-in essence, that New York law permitted pleas to the impossible crimes of attempted reckless and felonious assault. Nonetheless, it was additionally argued that rather than address that issue in the first instance, if exhausted, the court should remand to the Board to permit it the opportunity to discern whether a plea could be pursuant to any of the four subsections, rather than solely those two which would render Dale's conviction an aggravated felony. ${ }^{194}$ The court declined to remand on this basis, however, as the relevant issue concerned New York state law, not an area where the Board could exercise its expertise: "Although the BIA possesses expertise in interpreting immigration regulations and applying those regulations to the facts of an immigration case, it brings no specialized knowledge and expertise to the issue at hand-the proper interpretation of New York criminal law."195 Accordingly, the court addressed the issue in the first instance, held that a plea could be pursuant to any of the four subsections of the statute, and remanded for further proceedings concerning the documentation that would be necessary to establish the facts of the conviction. ${ }^{196}$

\section{The Sixth Circuit}

Like the Fourth Circuit's decision in Hussain, the Sixth Circuit's decision in Karimijanaki $v$. Holder represents the court's willingness to resolve an unaddressed legal issue on an undisputed factual record. ${ }^{197}$ In Karimijanaki, an immigration judge held that the petitioners, a mother and her son, abandoned their lawful permanent resident status in the United States after a prolonged absence of seven years, and that the son was not automatically entitled to U.S. citizenship based on the naturalization of his father. ${ }^{198}$ The Board dismissed

another participant if there be any, causes serious physical injury to a person other than one of the participants." N.Y. Penal L. § 120.10 .

193 Dale, 610 F.3d at 296.

194 Id. at 299.

195 Id.

196 Id. at 300-01.

197 See Karimijanaki v. Holder, 579 F.3d 710, 721 (6th Cir. 2009).

198 Id. at 714. 
petitioners' administrative appeal, but did not address the claim that the petitioner-son acquired citizenship automatically by virtue of his father's naturalization. ${ }^{199}$ On petition for review to the Sixth Circuit, the court held that the record evidence supported the agency's finding that the petitioner-mother abandoned her lawful permanent resident status by her prolonged absence from the United States and the circumstances attendant upon that absence. ${ }^{200}$ The court further held, in a matter of first impression, that the finding of intent regarding the mother was properly imputed to the son, thus resulting in a holding that he, too, abandoned his lawful permanent resident status. ${ }^{201}$

This left only the claim that the son automatically acquired citizenship upon the naturalization of his father, a claim the Board failed to address. ${ }^{202}$ "Generally, where an issue was ruled upon by the IJ and properly appealed to the Board but not addressed by the Board, the issue is not ripe for our review and should be remanded for the Board's consideration." ${ }^{203}$ Citing the Second Circuit's decision in Xiao $J i$ Chen, however, the court wrote that "a remand is not required where such a gesture would be futile." ${ }^{204}$ Under the INA, to have acquired citizenship automatically by virtue of his father's naturalization, the son must have been "residing in the United States in the legal and physical custody of the citizen parent pursuant to a lawful admission for permanent residence." 205 The immigration judge had held that the son was not residing "in his citizen father's physical custody at the time of his naturalization or at any time thereafter," and the Sixth Circuit held that the record did not compel the contrary conclusion. ${ }^{206}$ As the factual undergirding of the citizenship claim was clear, the only issue remaining was the purely legal question of whether the facts established circumstances that would give rise to the automatic conferral of citizenship on the son. The Court reached this legal issue despite no prior Board decision, and held that the agency, i.e., the immigration judge, "did not err in ruling that [the son] did not acquire citizenship because he did not reside in his citizen father's physical

\footnotetext{
199 Id.

200 See id. at 719.

201 See id. at 719-21.

202 Id. at 721.

${ }^{203}$ Id. (citing Matovski v. Gonzales, 492 F.3d 722, 740 (6th Cir. 2007) (citation omitted)).

204 Karimijanaki v. Holder, 579 F.3d 710, 721 (6th Cir. 2009). (citing Xiao Ji Chen v. U.S. Dep't of Justice, 471 F.3d 315, 339 (2d Cir. 2006).

${ }^{205}$ Id. (citing INA $\S 320(\mathrm{a})(3), 8$ U.S.C. $\S 1431(\mathrm{a})(3)$ ).

${ }^{206}$ Id.; see INA $\S 242(\mathrm{~b})(4)(\mathrm{B}), 8$ U.S.C. $\S 1252(\mathrm{~b})(4)(\mathrm{B})$.
} 
custody at the time of his naturalization or at any time thereafter."207 Accordingly, the court denied the petition in its entirety. ${ }^{208}$

\section{The Seventh Circuit}

The Seventh Circuit decision in Shou Wei Jin v. Holder returns this review to factual findings. ${ }^{209}$ The agency denied asylum and withholding of removal to a Chinese national and citizen who alleged eligibility for such relief and protection based on China's coercive family planning policies. ${ }^{210}$ Specifically, the agency held that the alien did not establish that he was married to his partner, who purportedly suffered a forced abortion, and that he otherwise failed to establish a well-founded fear of persecution "due to his resistance to China's population control policies." 211

The court held that the agency's analysis of whether the alien was married, whether traditionally or based on the notion of a common-law analysis, was erroneous and incorrect as a matter of law. ${ }^{212}$ Nonetheless, the court concluded that "a remand would be futile . . . because Jin presented no evidence that he personally suffered persecution as a result of China's population control policies." ${ }^{13}$ Under the governing law, an alien must establish that they themselves suffered persecution or would suffer persecution pursuant to China's population control policy or for resisting its implementation, regardless of his or her marital relationship with somebody who can establish such eligibility, i.e., there is no presumption of persecution for the spouse of an individual who has been persecuted. ${ }^{214}$ The agency noted in Jin's case that he did not suffer any persecution himself, nor did he ever attempt to resist implementation of the family planning policy. ${ }^{215}$ The court agreed: "Jin did not present any evidence that he suffered persecution-or that he will suffer persecution-as a result of any acts of resistance in which he engaged." ${ }^{216}$ This factual determination foreclosed his eligibility for asylum and withholding of removal regardless of whether he was married or not, and thus his petition for review was denied. ${ }^{217}$

\footnotetext{
207 Karimijanaki, 579 F.3d at 721-22.

208 Id.

209 See generally Shou Wei Jin v. Holder, 572 F.3d 392 (7th Cir. 2009).

${ }^{210}$ Id. at 394. See INA $\S 101(\mathrm{a})(42)(B), 8$ U.S.C. $\S 1101(\mathrm{a})(42)(\mathrm{B})$.

${ }^{211}$ Shou Wei Jin, 572 F.3d at 394.

${ }^{212}$ Id. at 395-96.

213 Id. at 396.

214 Id. at 396-97 (citing Matter of J-S-, 24 I. \& N. Dec. 520 (A.G. 2008), overruling Matter of C-Y-Z-, 21 I. \& N. Dec. 915 (BIA 1997)).

215 Id. at 397.

${ }^{216} I d$.

217 Id. at 398 .
} 


\section{The Ninth Circuit}

Ethnic Chinese and Christians have a long and troubled history in Indonesia, and have a significant share of the asylum claims arising in the pacific states of this country. ${ }^{218}$ Nonetheless, their claims have enjoyed only a modicum of success as of late. In Halim v. Holder, the Ninth Circuit was called upon to review the agency's denial of an ethnic Chinese Christian Indonesian's claim for asylum, which was denied on the ground that the applicant could not credibly establish past persecution or a well-founded fear of persecution on account of either religion or ethnicity. ${ }^{219}$ The court concluded that the record did not compel a finding that the alleged past acts of harm rose to the requisite level of severity to constitute persecution under the INA, and that the record similarly failed to compel a finding that the applicant possessed an objectively reasonable fear of persecution if removed to Indonesia. ${ }^{220}$

On review, the petitioner alien (Halim) contended that he was entitled to relief under the Ninth Circuit's disfavored group analysis, an intervening line of cases in which an applicant may establish eligibility for asylum by demonstrating that he is a member of a disfavored group and that he possesses an individualized risk of persecution on that ground. ${ }^{21}$ As this analysis was largely an intervening development, there was no agency decision applying this law to the facts alleged by Halim. Nonetheless, the court denied that Halim presented a legitimate claim to asylum under the court's disfavored group approach, and thus declined to remand proceedings. ${ }^{222}$ First, although there was certainly harassment and intimidation of ethnic Chinese and Christians in Indonesia, the court discerned no pattern or practice of persecution, and thus the claim that Halim belonged to a disfavored group was weak. ${ }^{223}$ Second, despite the prevalence of such acts, the record was clear that the government of Indonesia did not condone the harassment and had taken remedial steps. ${ }^{224}$ Finally, Halim failed to

\footnotetext{
218 See, e.g., Lolong v. Gonzales, 400 F.3d 1215, 1217-18 (9th Cir. 2005) (recounting this history), overruled by Lolong v. Gonzales, 484 F.3d 1173 (9th Cir. 2007) (en banc). See also Sael v. Ashcroft, 386 F.3d 922, 923-24 (9th Cir. 2004) (recounting the history).

219 Halim v. Holder, 590 F.3d 971, 974-75 (9th Cir. 2009).

220 See id. at $975-77$.

${ }^{221}$ Id. at 975, 977-78. See Sael, 386 F.3d at 922 (establishing analysis for asylum claims); Wakkary v. Holder, 558 F.3d 1049, 1059-67 (9th Cir. 2009) (extending analysis to claims for withholding of removal). See generally Lolong, 484 F.3d at 1179-81 (applying analysis).

${ }^{222}$ Halim, 590 F.3d at 978 (Halim "failed to make the minimal showing necessary to require that the agency reconsider its denial of relief.").

${ }^{223}$ Id. at $978-79$.

224 Id. at 979.
} 
credibly establish a particularized or individualized risk of persecution, distinct from other ethnic Chinese or Christians in Indonesia, so as to establish a well-founded fear of persecution. ${ }^{225}$

In so resolving this issue, the court was not unaware of the general proscription of Ventura: "We recognize that given our limited role in reviewing orders of removal, we may not decide in the first instance an issue entrusted to an administrative agency." 226 The court based its decision not to remand on three grounds:

First, we are affirming rather than reversing the agency. Second, in the decision denying relief, the IJ recognized that Halim was alleging a pattern of harassment and discrimination based on his ethnicity. Third, Halim has not made a prima facie showing that he might be entitled to relief under our disfavored group analysis." 227

These considerations militated against remand, and thus the court simply denied the petition for review. ${ }^{228}$

Judge Cudahy of the Seventh Circuit, sitting by designation, concurred in a separate opinion. ${ }^{229}$ He noted that under other circumstances, the situation presented by Halim's petition would require a remand to the agency so that it could consider, in the first instance, his claim under the intervening law. ${ }^{230}$ Judge Cudahy nonetheless agreed that the petition should not be remanded on the distinct ground that because Halim's claim was found not credible by the agency, there was no credible evidence to support a claim under the disfavored group analysis and thus only one possible resolution of that issue-Halim could not establish eligibility for asylum: ${ }^{231}$ "[w]here, as here, remand would be futile because there is no credible evidence that could support findings that the petitioner faced an individualized risk of future persecution, we need not remand even though more recent caselaw has clarified the weight of pattern or practice evidence." ${ }^{232}$

${ }^{225}$ Id. See Lolong, 484 F.3d at 1181 ("Lolong has provided nothing that suggests that her fears are distinct from those felt by all other ethnic Chinese Christians in Indonesia. Nor has she shown that all ethnic Chinese Christians in Indonesia have, based on the circumstances there, a well-founded fear of persecution. Although we are sympathetic to the plight of such peoples, we understand the BIA's decision to preclude a general grant of asylum to Indonesian Chinese Christians, and the record supports such a decision.").

${ }^{226}$ Halim, 590 F.3d at 979 (citing INS v. Ventura, 537 U.S. 12, 16-17 (2002)).

${ }^{227}$ Id. at $979-80$.

228 Id. at 980 .

${ }^{229}$ Halim, 590 F.3d at 980 (Cudahy, J., concurring).

230 Id.

231 Id. (citing, inter alia, Mattis v. INS, 774 F.2d 965, 967 (9th Cir. 1985) (holding that the court cannot affirm the Board on a ground it did not articulate)).

232 Id. 
In addition to Halim, the Ninth Circuit's decision in SotoOlarte offers an explanation of when remand may be required concerning a discrete factual issue-reversal of the agency's credibility determination. ${ }^{233}$ Soto-Olarte and his wife, both citizens of Peru, applied for asylum in the United States based on alleged persecution at the hands of the "Shining Path" terrorist organization. ${ }^{234}$ The immigration judge's holding, later affirmed by the Board, denied these applications on the ground that Mr. Soto-Olarte was not credible, as there were numerous inconsistencies between his testimony, declaration and the relevant police report regarding the main incident of alleged persecution. ${ }^{235}$ On petition for review, the Ninth Circuit agreed that the noted inconsistencies were material, but held that they could not, at that time, support the adverse credibility determination because Soto-Olarte had offered at least one explanation for an inconsistency which was not considered by the agency, and was otherwise not given the opportunity to address the other areas of concern ultimately relied upon by the immigration judge. ${ }^{236}$

Having determined that the credibility determination was not supported by substantial evidence, the court then addressed the Ninth Circuit's "deemed credible" rule where, on remand, the Court had at times "required the agency to accept the [alien's] testimony as true" following the reversal of an adverse credibility determination. ${ }^{237}$ The Ninth Circuit noted that it still remanded cases with an open record following the advent of the "deemed credible" rule, and that the cases applying that rule did not establish a definitive or always-applicable set of criteria for its application. ${ }^{238}$ While disclaiming any intent to do so, the panel noted distinctions in those cases applying, and declining to apply, the deemed credible rule. First, "[i]f it is apparent from the record before us that the IJ and the BIA have listed all possible reasons to support an adverse credibility determination, and they are inadequate in law or not supported by substantial evidence, then there may be cases where on remand we can sensibly say that a petitioner should be deemed credible." 239 Second, "if there is a reasonable prospect from the administrative record that there may be additional reasons upon which the IJ or BIA could rely, then it is appropriate to remand in a way that permits the agency to provide those reasons."240 The Court noted the preference for erring on the side of an open re-

233 Soto-Olarte v. Holder, 555 F.3d 1089 (9th Cir. 2009).

234 Id.

235 Id.

236 Id. at 1091-92.

237 See id. at 1093.

238 Id. at 1094.

239 Id. at 1095.

240 Id. 
mand: "in any case in which there are doubts about whether there may be other grounds for rejecting credibility, we should not restrict the BIA or an IJ." ${ }^{241}$ Citing to Ventura, the court remanded Soto-Olarte's claim on an open record without requiring that the agency deem him credible on remand. ${ }^{242}$

Kyong Ho Shin $v$. Holder again highlights the interplay between the remand rule of Ventura and the deference that is normally owed the agency's interpretation of the statutes and regulations it is charged with administering. ${ }^{243}$ The petitioners, a brother and sister, obtained lawful permanent resident status through their mother who, unbeknownst to them, obtained her "lawful" status via an immigration broker, i.e., fraudulently. Brother and sister Shin were charged with removability on the grounds that they lacked a valid immigrant visa at the time of their entry to the United States. The agency sustained the charge of removability and additionally denied their applications for a waiver of inadmissibility under section $212(\mathrm{k})$ of the INA, basing that decision on the ground that they were statutorily ineligible for such a waiver as lacking a visa and being otherwise inadmissible. ${ }^{244}$

The Ninth Circuit upheld the agency's determination that petitioners were removable. ${ }^{245}$ It reversed the Board's holding regarding the waiver of inadmissibility, however, held that petitioners were statutorily eligible for a waiver, and remanded solely for the adjudication of their applications on the merits. ${ }^{246}$ In reaching this determination, the court specifically held that to establish statutory eligibility for a section $212(\mathrm{k})$ waiver, an alien must be inadmissible under, inter alia, section 212(a)(7)(A)(i) of the INA, in possession of an immigrant visa,

241 Id.

242 Id.

243 Kyong Ho Shin v. Holder. 607 F.3d 1213 (9th Cir. 2010).

244 Attorney General's discretion to admit otherwise inadmissible aliens who possess immigrant visas:

Any alien, inadmissible from the United States under paragraph (5)(A) or (7)(A)(i) of subsection (a) of this section, who is in possession of an immigrant visa may, if otherwise admissible, be admitted in the discretion of the Attorney General if the Attorney General is satisfied that inadmissibility was not known to, and could not have been ascertained by the exercise of reasonable diligence by, the immigrant before the time of departure of the vessel or aircraft from the last port outside the United States and outside foreign contiguous territory or, in the case of an immigrant coming from foreign contiguous territory, before the time of the immigrant's application for admission.

INA $\S 212(\mathrm{k}), 8$ U.S.C. $\S 1182(\mathrm{k})$.

245 Kyong Ho Shin, 607 F.3d at 1216-18.

246 Id. at 1218-21. 
whether valid or not, and be otherwise admissible except for the ground of inadmissibility under the first prong of the statutory requirements. ${ }^{247}$ On the court's review of the facts, petitioners could meet these requirements, and there was otherwise no basis for concluding, as had the Board, that the statute required a valid immigrant visa in order to establish statutory eligibility for the waiver. ${ }^{248}$ The court then remanded solely for adjudication of the application, citing to Ventura for the proposition that the court could not issue a decision on that application in the first instance. ${ }^{249}$

Judge Wallace dissented from the majority's opinion on two grounds. ${ }^{250}$ First, Judge Wallace disagreed with the court's interpretation of the requirements for obtaining a waiver of inadmissibility under section $212(\mathrm{k})$, and cited evidence to the effect that the analysis and interpretation of the Board, rather than the court, was correct. ${ }^{251}$ Second, the first point aside, if there was disagreement with the Board's interpretation in its decision in the Shins' case, the proper route was to remand to the Board to allow it to render a definitive and precedential opinion, in line with both Ventura and Chevron, in the first instance, rather than to dictate to the Board what the statute required and remand only for adjudication. ${ }^{252}$

\section{The Eleventh Circuit}

Finally, the Eleventh Circuit's decision in Calle v. U.S. Attorney General provides the cap to that line of cases where the courts of appeals have reached out to resolve a legal issue without prior Board resolution. ${ }^{253}$ Ms. Calle, a native and citizen of Colombia, began her long administrative odyssey by applying for asylum, withholding of removal, and protection under CAT before an immigration judge. Her claim, based on a fear of persecution at the hands of the FARC, was rejected by both the immigration judge and, on appeal the Board. The asylum application was rejected on grounds of timeliness, and the remaining applications on their merits. Ms. Calle filed a motion to reconsider its decision with the Board, but this motion was denied. Persevering, she nevertheless filed a subsequent motion to reopen, arguing that country conditions had deteriorated in Colombia such that she would be targeted by the FARC if removed. The Board denied this motion, holding that she failed to establish her prima facie eligibility

\footnotetext{
247 Id. at 1219 .

248 Id. at $1219-20$.

249 See id. at 1221 (citing INS v. Ventura, 537 U.S. 12, 16-17 (2002)).

${ }^{250}$ Kyong Ho Shin, 607 F.3d at 1221-25 (Wallace, J., dissenting).

251 Id. at $1221-23$.

252 Id. at 1224-25.

${ }^{253}$ Calle v. U.S. Attorney General, 504 F.3d 1324 (11th Cir. 2007).
} 
for the relief sought. Petitioner again moved for reconsideration of the Board's decision, but the BIA denied this motion as numerically barred under the statute and regulation.

On petition for review, the Eleventh Circuit held that the Board erred in deeming the motion number-barred, as the regulations specify only that an alien is limited to one motion to reconsider a specific decision, not simply one motion to reconsider for the duration of any proceedings against her. ${ }^{254}$ Since the second motion to reconsider sought reconsideration of a decision distinct from Ms. Calle's appeal, it was more accurately characterized as her first motion to reconsider that decision, and thus not number-barred. ${ }^{255}$ The court then noted that the Board had not addressed the merits of the motion to reconsider, having denied the motion solely on number-barred grounds, and that the appropriate course at that stage would normally be to remand to the agency for further proceedings. ${ }^{256}$ The court declined to remand, however, holding that Calle's case fit within the "rare circumstances" exception of Ventura, as the unresolved issue in her case was legal and procedural rather than factual. ${ }^{257}$ The issue was whether there were grounds on which the motion to reconsider could be granted, and according to the court, that is an "objective, procedural inquiry; she either specified errors and supported them with pertinent authority, or she did not. Thus, in these 'rare circumstances' we feel comfortable deciding the issue left unresolved by the BIA in the first instance." 258 The court went on to hold that Calle's motion failed to adequately specify any errors of fact or law in the Board's decision denying her motion to reopen, and thus denied her petition for review on the merits, dispensing with remand. ${ }^{259}$

\section{IS THE EVOLVING FUTILITY JURISPRUDENCE IN TENSION WITH, OR COMPLEMENTARY TO, THE ORDINARY REMAND RULE?}

As a realistic matter, the federal courts of appeals are the last stop for a litigant. ${ }^{260}$ Thus, their implementation of the Supreme

\footnotetext{
${ }^{254}$ Id. at 1329; see INA $\S 240(\mathrm{c})(6), 8$ U.S.C. $\S 1229 \mathrm{a}(\mathrm{c})(6) ; 8$ C.F.R. $\S 1003.2(\mathrm{~b})$.

255 Calle, 504 F.3d at 1328-29.

${ }^{256}$ Id. at 1329 (citing INS v. Ventura, 537 U.S. 12 (2002).

257 Id. at 1330 .

258 Id.

259 Id. at 1331.

260 See John G. Roberts, JR., 2009 Year-End Report on the Federal Judiciary 2 (2009) (In 200957,740 cases were filed in the federal courts of appeals, while the Supreme Court issued 74 signed opinions out of 1,596 cases docketed.); see also David M. O'Brien, Join-3 Votes, The Rule of Four, The Cert. Pool, and the Supreme Court's Shrinking Plenary Docket, 13 J.L. \& PoL. 779 (1997); Kenneth W. Starr, The Supreme Court and Its Shrinking Docket: The Ghost of William Howard Taft,
} 
Court's dictates is of the utmost importance to a fully and fairly functioning judicial and administrative state. In the context of administrative law, this means that despite more or less clear directives from the Supreme Court regarding when matters must be returned to the agency for further proceedings, the discretion of the circuit courts to retain and decide matters in the first instance is great and largely unreviewable. This being said, is the post-Ventura futility jurisprudence in tension with the ordinary remand rule of Ventura? Or is it simply a concrete manifestation of Ventura's own recognition that there will be "rare circumstances" in which remand is not required? This question will have no clear resolution in this article, and, to echo Judge Friendly's dismay, it is unlikely that there is any bright shaft of light that would identify a clear means of decision in each and every case. Nonetheless, the consistency of the rationales of the circuit courts with Ventura can be judged within the broad scope of that decision, and a clearer path for future decisions can then be charted. Before any of that becomes "necessary," however, a threshold question must be answered: do these new futility cases in any meaningful way implicate the court's remand authority?

\section{A. Errors, Substantial Evidence, and the Possibility of Remand}

The cases addressed in Section III are explicitly couched in terms of the "futility of remand," making clear that, at the very least, the courts themselves believe that the issues raised and addressed implicate their authority to either remand or, in rare circumstances, to resolve an issue in the first instance without further agency involvement. Are the courts accurate in this characterization? The short answer is, only partially - a great number of these cases do not confront circumstances which would place the court in a Ventura-type situation, and this is especially true in the context of petitions raising adverse credibility issues. To understand why, it is necessary to understand the extremely deferential standard of review that the courts of appeals must utilize in addressing the Board's factual findings, including its eligibility determinations for asylum and withholding of removal.

Pursuant to section 242(b)(4)(B) of the INA, "the administrative findings of fact are conclusive unless any reasonable adjudicator would be compelled to conclude to the contrary." 261 On review before the courts of appeals, the burden is not on the government to establish that the administrative findings are supported by the record evidence, but rather on the petitioner-alien to establish that the record compels

90 Minn. L. Rev. 1363 (2006) (noting quantitative decline in Supreme Court's docket).

2618 U.S.C. $\S 1252(\mathrm{~b})(4)(B)$. 
the conclusion he would have the court make. To carry this burden, the petitioner-alien must point to record evidence that "not only supports a contrary conclusion, but indeed compels it." 262 As long as the record evidence does not compel the conclusion contrary to that reached by the agency, there will be no grounds for granting the petition for review when the issues are fact dependent rather than legal.

Accordingly, to the extent that the futility cases involve addressing factual issues on review, i.e., credibility determinations, eligibility determinations regarding asylum and withholding of removal, etc., the cases simply boil down to application of the INA's deferential standard of review to the facts of the particular cases, and thus do not in reality implicate any questions pertaining to remand or the futility of remand. First, regarding those cases where the court denies the petition despite the presence of errors in the underlying factual determination, all that is happening is the court's recognition of the fact that, even in light of the errors, the petitioner cannot establish that the record compels the conclusion contrary to that made by the agency. ${ }^{263}$ Remand as a live issue never comes into play because a circumstance that may require remand never arises-in failing to carry his burden in establishing that the record compels any reasonable adjudicator to accept his version of the facts, the petitioner necessarily fails to establish any basis on which the petition could be granted. Second, as a necessary corollary to this point, the courts' remand authority is not implicated when the court determines that the record does compel the contrary conclusion, thereby resolving the credibility issue or other factual controversy. As the Seventh Circuit noted in granting rehearing in Ghebremedhin, when the court applies the appropriate standard of review and finds that the agency erred, that determination "in no way disregards the agency's expertise and role as front-line evaluator of evidence." 264 Rather, the appellate resolution of the issue is consistent with the governing principles of administrative law, and the subsequent limited remand for further proceedings in light of the court's resolution of the factual issue, e.g., to permit the Attorney General an opportunity to exercise his discretion in granting or denying relief, does not implicate the court's general authority to

${ }^{262}$ Ouda v. INS, 324 F.3d 445, 451 (6th Cir. 2003) (quoting Klawitter v. INS, 970 F.2d 149, 151-52 (6th Cir. 1992)).

${ }^{263}$ See, e.g., Xiao Ji Chen v. U.S. Dep't of Justice, 471 F.3d 315, 339 (2d Cir. 2006) (declining to remand where evidence supported the agency's adverse credibility determination notwithstanding certain errors); Qyteza v. Gonzales, 437 F.3d 224, 228 (2006) (finding errors in the denial of an asylum application but declining remand where it was clear the same decision would be reached absent the errors); Lin v. Gonzales, 446 F.3d 395, 401 (2006) (adverse credibility determination sustained despite errors in the agency's consideration of that issue).

${ }^{264}$ Ghebremedhin v. Ashcroft, 392 F.3d 241, 243 (7th Cir. 2004). 
remand once an error has been discerned or, in the appropriate circumstances, to hold and decide the issue in the first instance.

What, then, to make of Judge Calabresi's statement in $\mathrm{Li} Z \mathrm{Zu}$ Guan that "to deny review in the face of EOIR errors, a court must have confidence that an error-free proceeding would yield the same result. The existence of substantial evidence supporting that result, without more, is not enough to give rise to such confidence." ${ }^{265}$ This statement is not correct for at least two reasons. First, it disregards the fact that it is the petitioner's burden to establish that the evidence compels the conclusion he argues the agency should have reached, not the government's burden to establish that the agency's findings are sufficiently supported by the record. As the burden is on the petitioner, if he cannot establish that the record as a whole compels the conclusion he advances, then it is irrelevant if there are some errors in the record-the only consideration is whether the record taken as a whole compels or fails to compel the relevant conclusion. Second, Calabresi's construction seemingly establishes a second test for reviewing agency factual determinations. Not only must the courts consider whether the record compels the contrary conclusion, but if there are some errors present, the record must fail to compel the contrary conclusion and the court must satisfy itself that the agency would have reached the same conclusion notwithstanding the purported errors. There is no textual support in the INA for such an approach, and it is, at bottom, a bizarre construction as the very fact that the record does not compel the contrary conclusion, notwithstanding the errors, would seem to be definitive regarding whether the agency would have reached a different conclusion absent the identified errors. Accordingly, contrary to the opinion of Judge Calabresi, if the record fails to compel the contrary conclusion regarding the factual issue in dispute, that is a sufficient condition on which to deny the petition rendering any recourse to "remand" language inapposite. ${ }^{266}$

Another situation where the courts' authority to remand cases is not seriously in play arises when there is a sufficient and independently dispositive basis on which to deny the petition, notwithstanding material errors in another aspect of the decision. As the Supreme Court has noted, "[a]s a general rule courts and agencies are not required to make findings on issues the decision of which is unnecessary to the results they reach." 267 Such a situation was presented to the

${ }^{265} \mathrm{Li} \mathrm{Zu}$ Guan v. INS, 453 F.3d 129, 138 (2d Cir. 2006). .

${ }^{266}$ But see id. at 137-38.("Where errors have been found in the EOIR decision, a residue of substantial evidence in support of the agency's result is a necessary, but not sufficient, condition for denial of review.").

267 INS v. Bagamasbad, 429 U.S. 24, 25-26 (1976), (citing, inter alia, Hirabayashi v. United States, 320 U.S. 81, 85 (1943) ("Since the sentences of three months each 
Seventh Circuit in Shou Wei Jin. ${ }^{268}$ There, despite errors in the agency's consideration of the alien's marriage, the governing law made clear that both a spouse and an unmarried partner would have to make the identical showings in order to establish eligibility for asylum under section 101(a)(42)(B) of the INA. Accordingly, although determining that the agency's marriage rationale was erroneous, the petition could nevertheless be denied on the dispositive basis that even if married, Jin failed to establish his eligibility for asylum. Likewise, in the Halim case, Judge Cudahy, concurring, would have based his decision to decline remand on the ground that the alien was found not credible in the underlying proceedings, and thus that finding infected the whole of any potential claim he could make. Instead of reaching out to address the issue of prima facie eligibility, the record evidence supported declining remand on the dispositive basis that the credibility determination foreclosed any avenues for relief or protection under the INA.

One final group of cases bears mentioning in this contextthose cases in which the Board would not have jurisdiction to address the issue if presented to it in the first instance, or where the Board lacks the relevant expertise under its mandate to give its decision deferential effect in the courts of appeals. The first situation is exclusively confined to constitutional challenges to the statute and regulations, which the Board lacks jurisdiction to address. ${ }^{269}$ In those circumstances, then, a court's remand authority is not implicated in addressing a constitutional claim in the first instance, as the court is the only appropriate venue for such a claim. The second situation reflects the fact that the Board will often have to address matters outside its own institutional purview in order to reach a decision regarding statutory or regulatory interpretation within its purview. The Fifth Circuit's decision in Dale, declining remand on the ground that the agency's interpretation of state criminal law is not entitled to any deference, highlights this distinction. If the agency cannot bring its expertise to bear on a given issue on remand, then there are no compelling justifications for remand and against judicial resolution of the issue in the first instance.

So a great number of the cases advancing futility claims can be reconciled with Ventura on the ground that they do not really impli-

\footnotetext{
imposed by the district court on the two counts were ordered to run concurrently, it will be unnecessary to consider questions raised with respect to the first count if we find that the conviction on the second count, for violation of the curfew order, must be sustained.")).

268 See supra Part III.B.5.

269 See, e.g., Severino v. Mukasey, 549 F.3d 79, 83 (2d Cir. 2008) (noting that exhaustion requirements do not apply to claims over which the Board lacks jurisdiction); Zeqiri v. Mukasey, 529 F.3d 364, 370 n.2 (7th Cir. 2008) (same).
} 
cate the courts' authority to remand or reach an issue in the first instance. This sampling of cases is not, however, exhaustive of the emerging futility jurisprudence. The Sixth Circuit in Karimijanaki clearly reached an issue not addressed by the Board in a situation where there should have been at least a presumption of remand. Likewise, the Ninth Circuit's Halim decision embraces a rather expansive role for the court in determining an alien's eligibility for relief pursuant to intervening case law, notwithstanding the fact that the agency did not and could not have resolved the relevant issue first, administratively. Finally, the Second Circuit's decision in Ucelo-Gomez seems to extend the court's authority to its apogee, as its determination that it could, in certain circumstances, decide whether facts established a particular social group under the INA is a blatant encroachment on the agency's primacy in interpreting the INA. Thus, Ventura and the ordinary remand rule are clearly implicated by this evolving jurisprudence. The purpose of the following section is to discern whether this jurisprudence represents a permissible construction of the courts' authority vis-à-vis the primacy of the agency, or whether the courts have overstepped the legitimate bounds of their reviewing function.

\section{B. Futility vs. Remand}

The prism through which this section must proceed is Ventura's own recognition, consistent with general administrative law principles, that there will be rare circumstances in which the courts of appeals may dispense with remand and resolve an issue in the first instance. $^{270}$ The "ordinary remand rule" acts as a strong presumption in favor of administrative primacy in resolving issues within the agency's competence, but that presumption, as noted by the Supreme Court and the various courts of appeals, may be rebutted when certain circumstances are present. Those circumstances were traced earlier in this article, ${ }^{271}$ and it must be assumed that any exception to the ordinary remand rule will broadly mirror those prior decisions. ${ }^{272}$ Nonetheless, before proceeding, it is also worth noting that simply because a court concludes it may decide an issue without remand does not mean it must do so. It is a decision that is left to the court's discretion once a "rare circumstance" is presented, and there are strong rationales for remanding proceedings even in such circumstances. As Judge Friendly wrote,

270 INS v. Ventura, 537 U.S. 12, 16 (2002) (citing Fla. Power \& Light Co. v. Lorion, 470 U.S. 729, 744 (1985)).

271 See supra Section I.A.

272 See, e.g., NLRB v. Wyman-Gordon, Co., 394 U.S. 759, 766 n.6 (1969); George Hyman Const. Co. v. Brooks, 963 F.2d 1532, 1539 (D.C. Cir. 1992). 
[I]f the courts suspect that an agency is not truly carrying out the purpose of a statute, no matter what its professions, reversals for inadequate or erroneous subsidiary findings will require the agency to rethink the problem and, if it adheres to the previous decision, to state its position in a manner that may provoke a ruling on an issue of law. ${ }^{273}$

In those situations, remand may be more beneficial to the litigants and the system in general, notwithstanding the courts' conceded authority to dispense with remand.

Remand may be dispensed with under Ventura's "rare circumstances" exception where the court determines that, on a clear factual record, "only one disposition is possible as a matter of law."274 The Sixth Circuit's Karimijanaki decision is the clearest exemplar of this class of case in the current review. The court determined that no reasonable adjudicator would be compelled to conclude to the contrary of the agency's factual findings, leaving only the legal issue of whether the facts alleged established the son's entitlement to citizenship. The Board did not address this issue, but the court dispensed with remand on the argument that, pursuant to the agency's determination of the facts, the son was necessarily foreclosed from establishing citizenship, i.e., there was only one permissible legal resolution of the relevant issue. Decisions such as the Karimijanaki case do not impermissibly encroach on agency prerogatives. The agency's primacy in factfinding was clearly recognized and safeguarded by the court's decision, as the ultimate legal conclusion was based on the facts as found by the agency. Moreover, the immigration judge had already reached the same conclusion; it was only the Board that had not explicitly addressed the citizenship claim.

In other circumstances, however, especially in situations where the factual record is not as clear, the court has reversed certain findings of fact, or it is apparent that no administrative adjudicator has considered the issue, the presumption of remand should probably operate unrebutted. A remand would less obviously be futile, and the court would run a greater risk of trammeling on the factfinding mission of the agency. Unfortunately, and again, the dividing line here is subjective and the ultimate decision on review necessarily discretionary. This is perhaps best illustrated by the divided panel of the Fourth Circuit in Hussain, where the majority believed it was solely addressing the legal issue of eligibility for adjustment of status, while Judge Hamilton believed any resolution of that issue involved both fact-finding and questions of law. In such cases where the dividing line between a

273 Friendly, supra note 3, at 224.

274 George Hyman Constr. Co., 963 F.2d at 1539. 
legal question and a factual question blurs, or where the resolution of a legal question will necessarily involve fact-finding not previously undertaken by the agency, proceedings should be remanded. Additionally, if the agency has not been afforded the opportunity to exercise its authority to render a precedential decision on an issue of statutory interpretation, remand should be undertaken to allow it that opportunity. In Shin, the Ninth Circuit erred in this regard by rendering an interpretation of a statutory provision without permitting the Board the opportunity to address the issue on remand. In his dissent, Judge Wallace noted that this deprived the Board of the chance to bring its expertise to bear on the issue and render a decision entitled to substantial deference on review before the courts of appeals. Although erroneous, the Ninth Circuit's decision does not represent a definitive encroachment on administrative competence, as the Board has the prerogative to render a contrary and precedential opinion on remand under the Supreme Court's dictate in Brand X. Nonetheless, courts should be wary of rendering statutory interpretations of the INA without a prior precedential resolution by the Board.

In any event, a court should be wary of reaching too far to resolve a "legal issue," paying close heed to the territory it must traverse to eventually reach that issue. The more resolution of the legal issue is tied to compelling administrative factual findings, accepted by the court on review, the more likely it is that remand could be safely dispensed with. The heavier the court's hand is in assessing, reversing, or questioning the administrative findings of fact, the less it should feel confident in resolving the issue, even if legal in nature, in the first instance.

Outside the context of purely legal issues, when may the court dispense with remand and resolve a fundamentally factual question in the first instance? This issue is posed clearly by the Ninth Circuit's decisions in Halim and Soto-Olarte, the Fifth Circuit's decision in Zhao, and the Second Circuit's decision in Ucelo-Gomez. The short answer is: never. The courts of appeals should never reach out to decide a factual issue unaddressed by the agency or which, when cleansed of its errors, could admit of multiple permissible answers. ${ }^{275}$

Before giving a longer answer to this question, the Ninth Circuit's justifications for dispensing with remand warrant consideration. In Halim, the court did not simply decide the relevant issue and thus deny the petition-it recognized that the arguments raised by the peti-

\footnotetext{
275 Again, when the record fails to compel a conclusion, or does compel a conclusion, the courts' decision is not implicating its remand authority. That is not the circumstance presented here. Here, the issue concerns factual issues unaddressed or erroneously addressed by the agency which make the very application of the compelling evidence standard impossible.
} 
tioner necessitated consideration of whether remand would be the appropriate course of action. ${ }^{276}$ It ultimately declined remand on three bases: first, because it was ultimately affirming rather than reversing the decision of the Board; second, because the agency considered a functionally similar claim in the course of denying the underlying application for asylum; and third, because the petitioner did not establish prima facie eligibility for relief pursuant to the relevant analysis. ${ }^{277}$ These rationales are unconvincing and fail to establish that the court acted within the permissible bounds of its authority in denying the petition rather than remanding for further proceedings.

The court's first reason, that it may decide an issue not addressed by the agency simply because by so deciding it has the effect of denying the petition, is not colorable. In Chenery, the Supreme Court was clear that remand should not be dispensed with simply because by doing so the agency action at issue would be left standing: "For purposes of affirming no less than reversing its orders, an appellate court cannot intrude upon the domain which Congress has exclusively entrusted to an administrative agency." 278 Moreover, the court's construction of its authority in this context runs afoul of the general proscription that a court cannot affirm an agency decision on a ground that the agency did not articulate. Here again Chenery is instructive: "We ... hold that an administrative order cannot be upheld unless the grounds upon which the agency acted in exercising its powers were those upon which its action can be sustained." ${ }^{279}$ The long-standing practice of the Ninth Circuit is consistent with this formulation, ${ }^{280}$ although it should be clear that Halim runs counter to this rule-at least one ground on which the petition was denied was not addressed by the agency. Finally, this reasoning by the court misapprehends the animating motive behind the ordinary remand rule. There is a presumption of remand not to safeguard a decisional outcome, but to safeguard the administrative decision making process itself. ${ }^{281}$ The ordinary remand rule exists to vouchsafe the agency's primacy in conducting the appropriate fact-finding and applying the law to those

\footnotetext{
${ }^{276}$ Halim v. Holder, 590 F.3d 971, 979-80 (9th Cir. 2009).

277 See id.

278 SEC v. Cenery, 318 U.S. 80, 88 (1943).

279 Id. at 95.

280 See, e.g., Mattis v. INS, 774 F.2d 965, 967 (9th Cir. 1985). (“[T]he BIA's denial of relief can be affirmed only on the basis articulated in the decision, and we cannot assume that the BIA considered factors that it failed to mention in its decision.") (internal citations omitted).

281 Cf. Friendly, supra note 3, at 224 ("Refusal to reverse on the basis of a judicial belief that the agency is certain to come to the same conclusion is rarely objectionable to the agency, however painful it may be to a litigant who would profit by the delay incident to even a fruitless remand.”).
} 
facts, not to protect a substantive outcome that is favorable to the government, of which the agency is but a part. To say that remand is less important because the effect of the courts declination is to leave an agency decision standing misses the point. In those circumstances, no less than in those where the court determines that the agency action cannot stand, remand is necessary to permit the agency the opportunity to undertake the relevant inquiry and investigation in the first instance, freed of any prior errors or, as in Halim, apprised of the need to apply intervening law to previously found facts.

The court's second stated justification is more convincing, but only superficially. This contention is at bottom the assertion that because the agency disposed of a claim similar to that which could be brought pursuant to its intervening "disfavored group analysis," the factual record was relatively complete, and the prior legal disposition of the application sufficiently analogous, so that the court could proceed to resolution of the new issue without the need for further agency proceedings. Yet the determination of whether an applicant can establish eligibility for asylum is a factual question statutorily committed to the Attorney General and his delegates. Even if no new additional facts would be adduced, and even if the agency had disposed of a similar claim in denying relief initially, the Board enjoys primacy in making the determination of eligibility. The status of the record on review and the nature of any legal issues previously resolved do not alter this division of authority. The Ninth Circuit's contention to the contrary was erroneous.

Its final justification, that the petitioner failed to establish prima facie eligibility for relief pursuant to its disfavored group analysis, reads like an implicit concession that the court overstepped the permissible bounds of its authority. The issue of prima facie eligibility for relief is the archetype of a determination that the agency must make in the first instance before a reviewing court may address the issue. This is all the more true in the context of asylum under the INA, where the statute unequivocally places responsibility for making such determinations in the hands of the Attorney General and his delegates. $^{282}$ The court's determination that the petitioner failed to establish prima facie eligibility does not act as a justification for declining remand, but is, rather, the clearest statement of what is wrong with the Halim decision and how clearly the court encroached on the primacy of the agency.

If the Ninth Circuit failed in justifying its decision not to remand in Halim, are there, nevertheless, legitimate bases on which the courts of appeals could reach a factual issue in the first instance? Again, and to return to the brief answer offered previously, there are

282 See INA $\S 208(b), 8$ U.S.C. $\S 1158(b)$. 
no readily conceivable circumstances where the court should decide a factual question without prior administrative resolution. Although the Second Circuit has noted in dicta that it could reach and decide a factual issue not addressed by the agency, it offered no citation or reasoned support for this bald proposition. ${ }^{283}$ The Ninth Circuit's "deemed credible" rule is equally lacking in any legal support, as it explicitly arrogates the agency's authority to weigh the credibility of applicants, and has, for good reason, been rejected by every other court of appeals. Most importantly in this context, it is not the domain of a reviewing court to address or resolve factual issues, whether that review is of agency action or an appeal from a district court. It is not sufficient to be able to "state with assured confidence" that a factual issue should be resolved in $x$ manner, ${ }^{284}$ as no matter how confident the court is in its resolution of the issue, the very act of reaching and resolving the issue is an encroachment on agency primacy. Thus, the situation presented by an unresolved factual question in the courts of appeals most closely approximates the absolutist tenor of Chenery, ${ }^{285}$ and it is in such circumstances where the courts should be loathe to take any action save remand.

The only potential scenario where the court could be excused in "overreaching" is, ironically, exactly that which the Halim decision presented and on which Judge Cudahy based his concurrence in the declination to remand. Judge Cudahy resolved the factual issue of eligibility in the first instance, but he did so on grounds already considered by the agency and which could be deemed dispositive of the disfavored group claim without the need to address the merits of that claim. By basing his concurrence on credibility, Judge Cudahy was acting within the permissible bounds of a reviewing court, even as he reached out to decide an issue not considered by the Board. These circumstances will be rare, being present only where the resolution of an administratively unresolved factual question can be disposed of simply

${ }^{283}$ See Ucelo-Gomez v. Gonzales, 464 F.3d 163, 170 (2d Cir. 2006) ("If a reviewing court can state with assured confidence (absent agency guidance as to its protectability under the INA) that a group would or would not under any reasonable scenario qualify as a 'particular social group,' it need not remand, and may rule on the issue in the first instance.").

${ }^{284}$ See id. See also Guendelsberger, supra note 106, at 636 ("Even if the court regards the evidence of record as so one-sided as to make the result on remand a foregone conclusion, the court should remand to the agency rather than evaluate whether reasonable factfinders could reach different conclusions based on the evidence.").

285 See SEC v. Cenery, 318 U.S. 80, 88 (1943) ("If an order is valid only as a determination of policy or judgment which the agency alone is authorized to make and which it has not made, a judicial judgment cannot be made to do service for an administrative judgment."). 
on application of an administratively resolved factual question. The role of fact-finder is one that the administrative agency is peculiarly well-suited to, especially in comparison to an appellate court whose central function is ensuring that the law is correctly discerned and applied. The agency also has specialized expertise in the matters within its purview, as well as institutional knowledge and memory. ${ }^{286}$ As the Supreme Court held in 1952,

Uniformity and consistency in the regulation of business entrusted to a particular agency are secured, and the limited functions of review by the judiciary are more rationally exercised, by preliminary resort for ascertaining and interpreting the circumstances underlying legal issues to agencies that are better equipped than courts by specialization, by insight gained through experience, and by more flexible procedure. ${ }^{287}$

In light of the purposes for which administrative agencies were instituted, it will be a rare day indeed when a court can make a colorable claim that remand is not necessary for agency disposition of a factual issue.

$* \quad * \quad *$

Where do these ruminations leave the courts of appeals? While there is no clear-cut answer that can be applied generally across the range of immigration cases, a guiding schematic can be discerned in the preceding.

First, there will be a presumption of remand in situations where the administrative agency has not yet addressed the relevant issue, or where the agency order does not clearly indicate the basis of its decision, or where the court has identified legal or factual errors in the decision on review. The issue of remand will not be implicated, however, in circumstances where, notwithstanding certain factual errors, the court determines that the record compels or fails to compel the conclusion advanced by the petitioners. In those cases, the court need only apply the compelling evidence standard to the facts, and resolve the issue via the appropriate standard of review. Likewise, the

286 See, e.g., Universal Camera Corp. v. NLRB, 340 U.S. 474, 488 (1951) ("[The NLRB is] one of those agencies presumably equipped or informed by experience to deal with a specialized field of knowledge, whose findings within that field carry the authority of an expertness which courts do not possess and therefore must respect.”); FCC v. Nat'l Citizens Comm. for Broad., 436 U.S. 775, 814 (1978) (same, regarding the FCC's handling of matters involving communications); Atl. Coast Line R.R. Co. v. Florida, 295 U.S. 301, 317 (1935) (same, regarding ICC's expertise in railroads).

${ }^{287}$ Far East Conference v. United States, 342 U.S. 570, 574-75 (1952). 
issue of remand will not be implicated if there is an independent and dispositive basis on which the court can deny the petition, notwithstanding errors in a different aspect of the agency's decision. Finally, remand is not at issue when the court confronts an issue in the first instance that would be outside the jurisdiction of the Board, or where the Board's expertise is not directly implicated by resolution of the issue.

Once the court apprehends that the petition presents an issue implicating its remand authority, it must categorize the issue raised, i.e., whether it is a legal or factual issue. If the issue is factual, the presumption of remand should be non-rebuttable, as the primacy of the agency is at its nadir in such circumstances. There are no colorable situations that would permit the court to decide a factual issue in the first instance, without prior resolution by the agency. Additionally, the court's "certainty" regarding the disposition of the issue cannot and should not operate to rebut the presumption of remand, as the presumption exists in large part to safeguard the primacy of the agency's factfinding. The only potential exception to this rule would be the situation presented in Halim, whereby the court can deny relief on the newly raised issue on the basis of a controlling finding already issued by the Board and upheld by the court.

On the other hand, if the issue is purely legal, the presumption of remand is rebuttable, but only on a heightened demonstration that remand would be futile. The court should assure itself that not only would the agency only be able to reach one decision on remand, but that there are compelling reasons outside the contention of futility that justify abrogating the agency's primary role. Such reasons may be akin to those presented in Karimijanaki, where the court decided the legal issue on a clear factual record and its resolution was consistent with at least one agency adjudicator. Situations where substantial harm to the litigants may arise on account of the delay inherent in even a futile remand may present similarly compelling reasons. In whatever circumstances are presented, however, the court should not rely simply on assertions of "futility" in reaching the legal determination absent prior administrative resolution. To paraphrase Judge Calabresi, futility is a necessary, but not a sufficient condition for denying remand. ${ }^{288}$ In order to adequately safeguard the prerogatives of the agency, and to ensure that the courts of appeals maintain the limits of their own authority, remand must be the prescribed course of action in all but the most extraordinary circumstances.

288 See Li Zu Guan v. INS, 453 F.3d 129, 137-38 (2d Cir. 2006). 


\section{CONCLUSION}

Over six decades have passed since Chenery, and nearly a decade since the ordinary remand rule was enunciated in Ventura. Nonetheless, deciding when to remand and when to hold a case is as much "art" today as it was when Judge Friendly published his review of the law in 1969. The dividing line may be apparent only as a matter of concrete impression, i.e., the courts will know it when they see it, ${ }^{289}$ and will be conscious of any appellate encroachment on administrative function. A transgression may only be realized in the rare circumstance of admonishment by the Supreme Court.

Despite the inherent discretionary and subjective nature of the remand determination, one clear line within the broader rules deduced here may be relevant and meaningful as a guide: common sense with adequate recognition of the interdependencies between the administrative state and the judiciary. Such was Judge Friendly's prescription: "[W]hile judges must be respectful of the policy-making and factfinding functions of the agencies, they need not-indeed, should notregard themselves and the agencies as working in completely watertight compartments. ... [W] [Wen sensibly applied [Chenery] and its related principles continue to be vital and useful doctrines of administrative law." $" 90$ A common-sense approach to remands would embody a robust conception of administrative primacy and judicial recognition that only in the rarest circumstances should an issue be reached and decided on review without prior agency resolution. This approach should also recognize that even in those rare circumstances where remand could be dispensed with, it should not be, unless there are compelling considerations which operate to negate the agency's primary role in interpreting and deciding issues pursuant to the statutes and regulations within its mandate. These guiding principles walk a narrow line of reconciliation between Friendly's purists and realists and, if sensibly applied by the courts of appeals, Chenery and Ventura will remain "vital and useful doctrines of administrative law" for the foreseeable future. ${ }^{291}$

${ }^{289}$ See Jacobellis v. Ohio, 378 U.S. 184, 197 (1964) (Stewart, J., concurring) ("I shall not today attempt further to define the kinds of materials I understand to be embraced within that shorthand description; and perhaps I could never succeed in intelligibly doing so. But I know it when I see it. . . .").

290 Friendly, supra note 3 , at 225.

291 Id. 
